\title{
Assessing the environmental sustainability of an emerging energy technology: Solar thermal calcination for cement production
}

DOI:

10.1016/j.scitotenv.2020.140510

\section{Document Version}

Accepted author manuscript

Link to publication record in Manchester Research Explorer

Citation for published version (APA):

Tomatis, M., Jeswani, H. K., Stamford, L., \& Azapagic, A. (2020). Assessing the environmental sustainability of an emerging energy technology: Solar thermal calcination for cement production. Science of the Total Environment, 140510. https://doi.org/10.1016/j.scitotenv.2020.140510

Published in:

Science of the Total Environment

\section{Citing this paper}

Please note that where the full-text provided on Manchester Research Explorer is the Author Accepted Manuscript or Proof version this may differ from the final Published version. If citing, it is advised that you check and use the publisher's definitive version.

\section{General rights}

Copyright and moral rights for the publications made accessible in the Research Explorer are retained by the authors and/or other copyright owners and it is a condition of accessing publications that users recognise and abide by the legal requirements associated with these rights.

\section{Takedown policy}

If you believe that this document breaches copyright please refer to the University of Manchester's Takedown Procedures [http://man.ac.uk/04Y6Bo] or contact uml.scholarlycommunications@manchester.ac.uk providing relevant details, so we can investigate your claim.

\section{OPEN ACCESS}




\title{
Assessing the environmental sustainability of an emerging energy technology: Solar thermal calcination for cement production
}

\author{
Marco Tomatis, Harish Kumar Jeswani, Laurence Stamford and Adisa Azapagic* \\ Sustainable Industrial Systems, Department of Chemical Engineering and Analytical Science, The \\ University of Manchester, Manchester M13 9PL, UK
}

${ }^{*}$ Corresponding author: adisa.azapagic@manchester.ac.uk

\begin{abstract}
Cement production is a highly energy-intensive process, contributing $7 \%$ to global $\mathrm{CO}_{2}$ emissions. Over $80 \%$ of the energy used in cement production is consumed by the calcination process. This paper considers a novel solar thermal technology for calcination, to investigate if it could help mitigate the climate change and other environmental impacts from cement production on a life cycle basis. The following three solar options are compared to conventional fossil-fuel calcination via life cycle assessment: a full solar system, which provides all the required thermal energy, and two hybrid systems, where the solar system provides $14 \%$ and $33 \%$ of the thermal energy, respectively. The results show that all three solar options have lower impacts than conventional calcination in 14 out of 17 categories. The full solar system is the best alternative, with major reductions in climate change (48\%), fossil depletion (75\%), photochemical ozone formation (92\%) and terrestrial ecotoxicity (79\%). Based on insolation levels in different parts of the world, the solar systems could be applied to $26 \%$ of current global cement production. This would reduce the climate change impact by $15-40 \%$, as well as most other impacts by $14-87 \%$, depending on the fuel mix. However, a limiting factor might be two times greater land occupation than by the conventional process. Furthermore, the solar system has higher human toxicity-cancer $(102 \%)$ and metals and minerals depletion $(6 \%)$ due to the construction of solar facilities. Coupling conventional calcination with carbon capture and storage (CCS) is more efficient in reducing the climate change impact $(63 \%)$ than the solar system $(48 \%)$ relative to conventional calcination without CCS. However, adding CCS to the solar calciner would still be a better option, decreasing the impact by $81 \%$ relative to conventional calcination without CCS. These findings will be of interest to the solar and cement industries as well as other industrial sectors using hightemperature processes.
\end{abstract}

Keywords: climate change; cement production; solar energy; environmental sustainability; life cycle assessment; solar calcination

\section{Introduction}

Cement is one of the most ubiquitous construction materials, with worldwide production exceeding 4.1 billion tonnes per year (CEMBUREAU 2018). It is produced from limestone and clay which are ground to fine powder, referred to as cement raw meal (CRM), and calcined at high temperature to create clinker. The latter is then milled and mixed with gypsum to produce cement. Owing to the energy-intensive production process, the cement sector is one of the main contributors to climate change globally, emitting 2.2 Gt $\mathrm{CO}_{2}$ annually, or $7 \%$ of global anthropogenic $\mathrm{CO}_{2}$ emissions (IEA 2019). Around $94 \%$ of these occur during the calcination process, which also accounts for over $80 \%$ of the total energy requirements in the production of cement (Tregambi et al. 2018). Within the calcination process, about $40 \%$ of the $\mathrm{CO}_{2}$ emissions are caused by the combustion of fossil fuels, while $50 \%$ are emitted directly by the calcination of limestone (Benhelal et al. 2013).

Several options are being considered by the cement industry in an attempt to reduce $\mathrm{CO}_{2}$ emissions, including use of alternative fuels (Bourtsalas et al. 2018, Georgiopoulou and Lyberatos 2018) and/or feedstocks (Mikhailova et al. 2013, Machner et al. 2018). In recent years, coupling cement production with carbon capture technologies has also been investigated (Li et al. 2013, Hills et al. 2016, Cormos et al. 2017). Another option is to use solar thermal energy (Meier et al. 2006) which has begun to receive increasing attention in recent years. 
Solar thermal energy can be used for the calcination of raw materials (Meier et al. 2005, Tregambi et al. 2018). In such systems, calcination takes place in a solar calciner (reactor) which receives a concentrated solar beam from a solar field (Moumin et al. 2019, Oliveira et al. 2019, Moumin et al. 2020). Different reactor configurations, including closed (e.g. fluidised bed reactor (Tregambi et al. 2018)) and open (e.g. rotary kiln (Moumin et al. 2020)) reactors are being investigated to determine the most effective set-up (Moumin et al. 2019). Since this novel technology is still under development (SOLPART 2019), it is important to investigate its environmental impacts using a whole-system approach and adopting life cycle thinking to mitigate any adverse impacts at the design stage.

Therefore, this study assesses for the first time the life cycle environmental sustainability of solar thermal calcination of CRM. The aim is to determine the potential role of solar thermal technology in reducing the carbon intensity of cement production with respect to the 2050 decarbonisation targets set by the industry (Cembureau 2013). A further aim is to consider the implications of decarbonisation for other environmental issues to ensure that climate change mitigation is not pursued at the expense of other impacts. A novel high-temperature solar thermal reactor, developed within the SOLPART project (SOLPART 2019), is considered for this purpose, together with the accompanying infrastructure. Three solar-based calcination scenarios are considered: a full solar system, with all the production carried out utilising solar thermal energy, and two hybrid systems, one comprising a third and another $14 \%$ of solar thermal, with the rest of the energy provided by other fuels used in the conventional calcining process. The environmental sustainability of these scenarios is compared to conventional calcination to determine any potential benefits or disadvantages of the solar thermal systems. Detailed descriptions of the scenarios and the components of the solar system are provided in Section 3. The next section provides a literature review focusing on different options in the cement industry aimed at reducing its environmental impacts. These are also compared to the solar system later in the paper.

\section{Literature review}

The environmental impacts of cement production have been studied widely through life cycle assessment (LCA) (Rahman et al. 2013, García-Gusano et al. 2014, Stafford et al. 2016). Results of these studies show that impacts from the cement industry are mainly caused by the large amount of fossil fuels and raw materials required by the production process (Yang et al. 2017, Cankaya and Pekey 2019). Thus, a number of LCA studies have assessed the implications of using alternative fuels and raw materials, as well as of coupling cement production with carbon capture, as discussed below.

Alternative fuels are utilised widely by the cement industry to reduce emissions of $\mathrm{CO}_{2}$ and other pollutants (Rahman et al. 2013, 2015), with an average fossil-fuel substitution rate of $13 \%$ reported on a global scale (Hasanbeigi et al. 2012). These include waste tyres, municipal solid waste, sludge and other types of waste. For example, LCA studies that investigated using sludge, waste oils, refuse- and tyre-derived fuels for a partial replacement (3.5-30\%) of fossil fuels for clinker production (Bourtsalas et al. 2018, Georgiopoulou and Lyberatos 2018, Cankaya and Pekey 2019) found that refuse-derived fuels led to greater reductions in environmental impacts compared to the other fuels. For example, Bourtsalas et al. (2018) estimated that using non-recycled plastic and paper refuse (with $80 \%$ biogenic carbon content) reduced $\mathrm{GHG}$ emissions from cement production by $89 \%$ ( $3 \mathrm{t} \mathrm{CO}_{2}$ eq./t fuel) compared to coal. This reduction was due to the lower $\mathrm{CO}_{2}$ emissions from fuel combustion (46\%) and the avoided methane emissions that would be generated if this refuse was landfilled. Another study (Hossain et al. 2019) reported a 16\% reduction in GHG emissions by utilising fuels derived from wood waste (at $20 \%$ substitution rate). Both this and the study by Bourtsalas et al. (2018) found that pollutant levels were below regulatory limits when alternative fuels are used, with no significant differences from the stack emissions produced by conventional fuels. However, the combustion of some alternative fuels, such as hazardous wastes, can release toxic pollutants, including dioxins and heavy metals, limiting their utilisation (Zemba et al. 2011, Holt and Berge 2018).

With regard to alternative raw materials, various options, including fly ash, pozzolans and slags, have been considered for the replacement of limestone (Damtoft et al. 2008, Habert et al. 2010). 
An LCA study (Hossain et al. 2017) investigating the use of fly ash and glass powder to substitute clinker, suggested that these materials could potentially reduce energy consumption and the related climate change impact from cement production. Similarly, Tosti et al. (2020) investigated the use of biomass fly ash as a clinker substitute (20-40\% substitution rate), reporting up to $26 \%$ reduction in GHG emissions. This also avoids the environmental impacts of fly ash landfilling. Ruan and Unluer (2016), who considered the use of dolomite or magnesite to produce magnesia cements, also reported lower impacts compared to conventional Portland cement made from limestone. However, they found that climate change, human toxicity and land use were 40-60\% higher. The higher climate change impact was attributed to the decomposition of magnesite, which releases $40 \%$ more $\mathrm{CO}_{2}$ than limestone. AzariJafari et al. (2019) also investigated the use of various additives, such as silica fume, zeolites and metakaolin, showing that alternative materials can increase the impacts of Portland cement production, mainly related to their transportation. Moreover, extraction of materials such as metakaolin led to higher resource depletion, while the use of silica fume increased human toxicity compared to the base case. However, regardless of environmental impacts, the use of alternative materials and additives for cement production may be dictated by external factors, such as technical feasibility, raw material availability and legal regulations (Damtoft et al. 2008, Habert et al. 2010).

The life cycle impacts of carbon capture and storage (CCS) technologies have been investigated extensively (Cuéllar-Franca and Azapagic 2015, Baena-Moreno et al. 2018); however, their application to cement production is fairly recent and, thus, few studies are available. For example, Garcia-Gusano et al. (2015) carried out a prospective LCA of Spanish cement production in 2030 and analysed the effect of $\mathrm{CO}_{2}$ capture by mono-ethanolamine (MEA). The results showed that using CCS in the Spanish cement sector could reduce the climate change impact by $15 \%$, ozone depletion by $27 \%$ and abiotic depletion by $11 \%$, but worsen all other categories, including an increase of $530 \%$ in human toxicity. An et al. (2019) also reported a large increase in human toxicity $(2100 \%)$ as well as in marine ecotoxicity $(250 \%)$ from post-combustion CCS, mainly due to the production of MEA and the combined heat and power unit. A similar increase was reported for freshwater ecotoxicity (up to 200\%) for oxy-fuel combustion, but this option had overall lower impacts as it mainly requires additional electricity for processing the gaseous emissions (An et al. 2019). Rolfe et al. (2018) also estimated the LCA impacts of oxy-fuel combustion used in cement production, in comparison with calcium carbonate looping $(\mathrm{CCL})$. The authors found that the latter could reduce the climate change impact by $89 \%$ relative to unabated operation. Some of the other impacts had net-negative values (savings) due to the credits for electricity generation. However, both CCL and oxy-fuel had higher toxicity-related impacts and fossil depletion (59-98\%) compared to the cement production without carbon capture.

Although there are no LCA studies on solar cement production, the environmental impacts of solar thermal energy have been investigated widely using LCA (Comodi et al. 2014, Beccali et al. 2016, Lamnatou and Chemisana 2017). For instance, Corona et al. investigated the effect of geographical location, including Africa, Europe, Middle-East and South-America, on the environmental impacts of concentrated solar power plants (Corona et al. 2016). The results showed that poor insolation increased the impacts of the plants as a larger solar field and more resources were needed. The use of solar thermal energy for heating and cooling systems has also been investigated, but most studies focus on domestic instead of industrial applications (Comodi et al. 2014, Souliotis et al. 2018, Gagliano et al. 2019). Domestic solar systems utilise different technologies (e.g. photovoltaic panels and flat plate collectors) and operate at much lower temperatures compared to the solar calcination system and hence they are not discussed further.

\section{Methodology}

The LCA study has been conducted according to the ISO 14040/14044 standards, following the attributional approach (ISO 2006a, 2006b). GaBi 8.7 software (Thinkstep 2019) has been used for system modelling. The goal and scope of the study are described below, followed by the inventory data and the impact assessment method in the subsequent sections. 


\subsection{Goal and scope definition}

The study has the following three goals:

i) to quantify the environmental impacts of solar thermal calcination and to compare it to the conventional system, with the aim of quantifying any benefits or disadvantages of this emerging technology for the cement industry;

ii) to identify the hotspots and opportunities for improvements to the solar system and the calcination process; and

iii) to estimate the potential global environmental implications of replacing conventional calcination by the solar thermal system proposed here, considering regions with suitable insolation levels.

Two functional units are considered to reflect the above goals of the study. For the first two goals, the functional unit is defined as "production of $1 \mathrm{t}$ of calcined cement raw meal". For the global implications, the analysis is based on "annual global production of calcined cement raw meal in regions with suitable insolation levels". Further details on the latter are provided in the inventory data section.

The scope of the study is from cradle to gate, with the system boundaries for both the solar and the conventional systems encompassing construction of calcination facilities, the calcination process and end-of-life waste management (Figure 1). The life cycle stages are detailed below, along with the scenarios considered in the study. The system is assumed to be installed in Alicante, Spain, based on the current cement production facility where the solar production facilities would be built (SOLPART 2019).
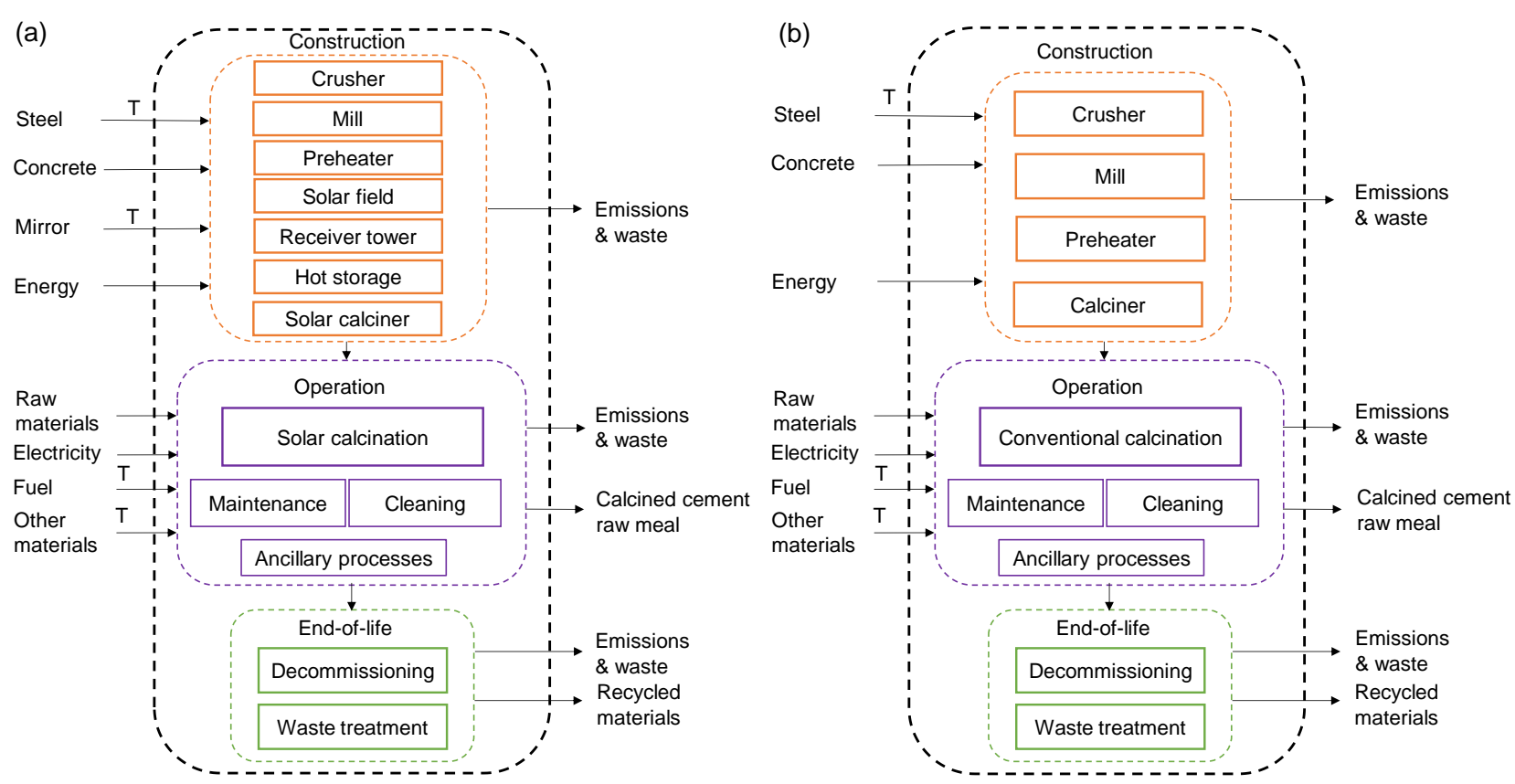

Figure 1 System boundaries for (a) solar-thermal calcination and (b) conventional calcination systems [T: transport].

\subsection{Inventory data and assumptions}

Inventory data for the construction and operation of both solar (Lopez 2019, SOLPART 2019) and conventional calcination facilities (Garcia Garcia 2019) have mainly been provided by the SOLPART project partners. As the solar facilities are at the development stage, materials and energy required to operate them have been estimated based on the design and experimental data from a pilot plant. These are detailed further below, following a description of the calcination scenarios considered in the paper.

\subsubsection{Calcination scenarios}

As outlined in Figure 2, cement production starts with the extraction of raw materials, including limestone, marl and sand. Raw materials are ground and mixed in the desired proportion to 
prepare CRM. The latter is then sent to the pre-heater tower where its temperature is increased to about $600^{\circ} \mathrm{C}$ by contact with hot air from the calciner and the kiln. The CRM flows by gravity to the calciner, where it is heated to $900^{\circ} \mathrm{C}$ by the heat from combustion of fuels, during which the limestone is calcined into lime according to the reaction: $\mathrm{CaCO}_{3} \rightarrow \mathrm{CaO}+\mathrm{CO}_{2}$. The calcined $\mathrm{CRM}$ is then sintered at about $1400^{\circ} \mathrm{C}$ in the kiln to produce clinker. The cement plant considered here operates $24 \mathrm{~h} /$ day and produces $3500 \mathrm{t} /$ day of calcined CRM. The clinker is subsequently cooled, mixed with additives (e.g. gypsum) and ground to produce cement.

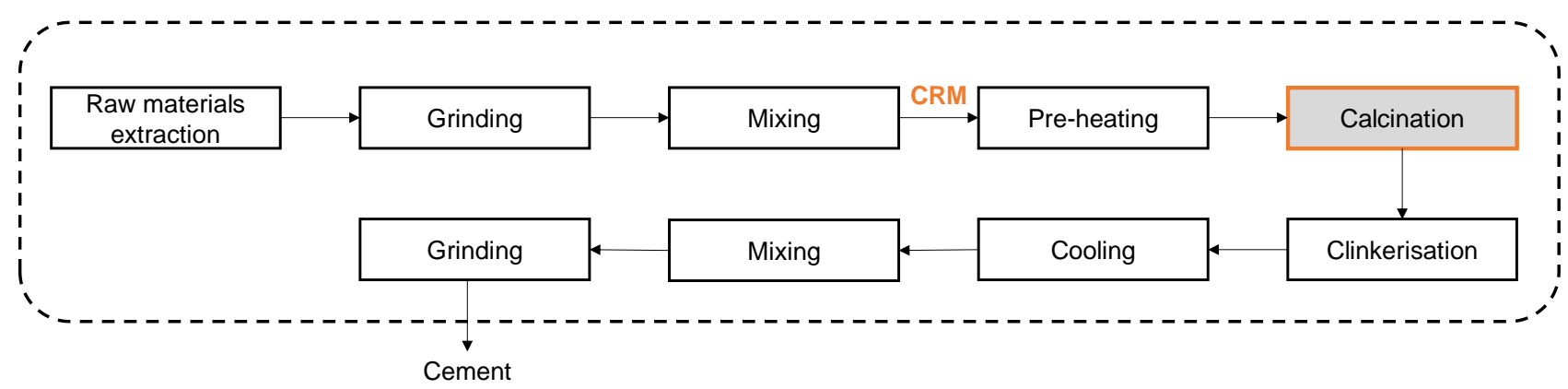

Figure 2 An overview of cement production [Calcination is shaded as it is the focus of the study. CRM: cement raw meal.]

The solar calciner has been designed to either fully replace or reduce the use of the current calciner, which is fuelled by petroleum coke, a fuel commonly utilised in cement production plants (Georgiopoulou and Lyberatos 2018, Tsiligiannis and Tsiliyannis 2019). For this reason, three solar scenarios are defined: one where the cement production is carried out solely in the solar calciner and two hybrid options where solar and conventional calcining are combined. The hybrid options are considered as industrial land availability might be a limiting factor since a large area is needed for the construction of the solar field (Kelly 2010). The hybrid systems would require less area due to a smaller solar field, while still reducing fossil fuel consumption and related $\mathrm{CO}_{2}$ emissions from the calcination process.

As indicated in Figure 3, the essential components of the solar calcination system are the solar field, receiver tower and solar calciner (reactor). The solar field is composed of a number of heliostats, which reflect sunlight towards the receiver tower, providing the thermal energy (heat) to the calciner necessary for the calcination reaction. The full solar system also includes a pre-heated storage, a hot storage and a second-stage pre-heater, while in the hybrid systems a conventional calciner also operates in parallel to the solar system to maintain the required production rate. In all three scenarios, the solar calciner is operated for 8 hours during daylight time, based on Alicante's average hours of sunshine per year of $2974 \mathrm{~h} / \mathrm{yr}$ (YMG 2020). An overview of the scenarios is provided below, with further details given in Table 1-Table 6.

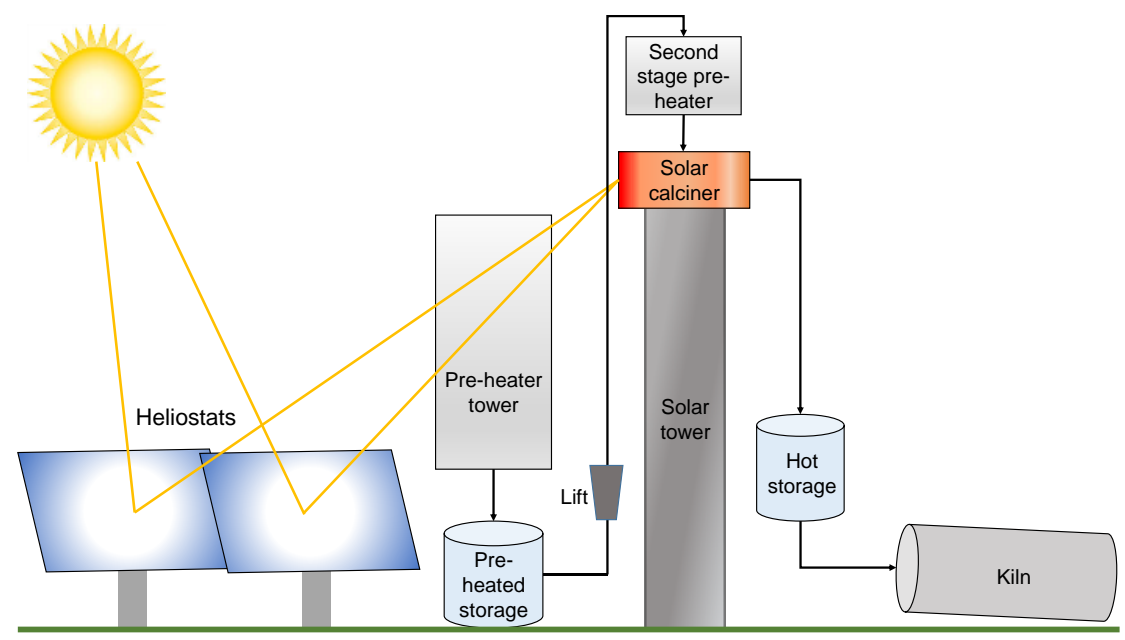

Figure 3 A schematic representation of solar facilities [Not to scale]. 
i. Full solar scenario

In this scenario, the solar system has a capacity of $438 \mathrm{t} / \mathrm{h}$ and produces all $3500 \mathrm{t} /$ day of calcined CRM over 8 hours. Thus, no fossil fuels are required for the calcination step. Since the cement plant operates $24 \mathrm{~h} /$ day, hot storage is necessary to interface the solar calciner with conventional facilities and allow continuous cement production. The CRM from the pre-heater is stored in a preheated unit at about $600^{\circ} \mathrm{C}$, which allows operation of the pre-heater outside daylight hours. Hot air from the kiln $\left(1400^{\circ} \mathrm{C}\right)$ is used to maintain the storage temperature. During daylight hours, stored CRM is sent via a lift to a second stage pre-heater (Figure 3 ), which raises its temperature to around $800^{\circ} \mathrm{C}$ with hot gases from the solar calciner. Hot CRM flows by gravity into the solar reactor where limestone is calcined. In total, 4910 heliostats are required to maintain the operating temperature of the calciner of $900^{\circ} \mathrm{C}$. Finally, the calcined CRM is directed to a hot storage unit, where its temperature is maintained at $850^{\circ} \mathrm{C}$ by hot gases from the kiln. As the kiln has a capacity of $145 \mathrm{t} / \mathrm{h}$ and has to operate continuously to reduce thermal shocks and costs, this feed rate of CRM is maintained over the course of 24 hours, allowing the cement plant to operate without interruption. The remaining CRM (293 t/h $=438-145 \mathrm{t} / \mathrm{h})$ is kept in the hot storage unit to maintain the required temperature and enable uninterrupted operation of the kiln.

\section{ii. Hybrid scenario 1}

The solar system in this scenario has a smaller capacity $(145 \mathrm{t} / \mathrm{h})$ and produces $1160 \mathrm{t} /$ day of calcined CRM over 8 hours, equivalent to $33 \%$ of the plant's production. The conventional calciner provides the remaining $2340 \mathrm{t} /$ day to maintain the desired production rate of $3500 \mathrm{t} /$ day. Notably, this hybrid set-up allows operating with the same capacity of conventional facilities and thus, hot storage and the second stage pre-heater are excluded from this design. Since the conventional calciner is on standby for $8 \mathrm{~h} /$ day, its energy losses are estimated at $104 \mathrm{GJ} /$ day (Dryden 1982). This plant configuration requires 2419 heliostats to operate the solar calciner.

\section{iii. Hybrid scenario 2}

Here, the solar calciner has a capacity of $63 \mathrm{t} / \mathrm{h}$ and produces $500 \mathrm{t} /$ day of calcined CRM, or $14 \%$ of the total daily production (3500 t/day). The remaining $3000 \mathrm{t} /$ day is produced by the conventional calciner, which operates at a reduced productivity of $83 \mathrm{t} / \mathrm{h}$ of calcined CRM while the solar calciner is in operation, and at the normal capacity of $145 \mathrm{t} / \mathrm{h}$ for the remaining time. No hot storage or second stage pre-heater are considered in this scenario since the solar and conventional calciners operate in parallel during daylight hours, while the conventional calciner operates independently during the rest of the day, maintaining the desired production rate.

\subsubsection{Construction of solar and conventional facilities}

Inventory data for the solar and conventional facilities are summarised in Table 1. Background LCA data for all materials and processes used in the construction of both the solar conventional facilities have been sourced from the Ecoinvent 3.5 database (Wernet et al. 2016). The data for materials and energy produced in Spain have been considered where available. Otherwise, Ecoinvent data have been modified to correspond to Spanish grid electricity. A transportation distance of $100 \mathrm{~km}$ has been assumed for the transport of materials with the exception of concrete, which is assumed to be produced on-site. Further inventory details for each solar component are provided below.

Table 1 Components of the solar and conventional calcination systems (SOLPART 2019)

\begin{tabular}{|c|c|c|c|c|c|}
\hline Item & $\begin{array}{l}\text { Full } \\
\text { solar }\end{array}$ & $\begin{array}{l}\text { Hybrid } 1 \\
\text { (33\% solar) }\end{array}$ & $\begin{array}{l}\text { Hybrid } 2 \\
\text { (14\% solar) }\end{array}$ & $\begin{array}{l}\text { Conven- } \\
\text { tional }\end{array}$ & Comments \\
\hline Heliostats (no.) & 4910 & 2419 & 1021 & - & Each with a surface area of $140 \mathrm{~m}^{2}$ \\
\hline Receiver tower (no.) & 1 & 1 & 1 & - & $120 \mathrm{~m}$ high \\
\hline Reactor irradiated surface $\left(\mathrm{m}^{2}\right)$ & 540 & 266 & 114 & - & \\
\hline Pre-heated storage (no.) & 1 & - & - & - & $\begin{array}{l}\text { Capacity: } 2320 \text { t of } \mathrm{CRM}^{\mathrm{a}}(=145 \\
\mathrm{t} / \mathrm{h} \times 16 \mathrm{~h})\end{array}$ \\
\hline Hot storage (no.) & 1 & - & - & - & $\begin{array}{l}\text { Capacity: } 2340 \mathrm{t} \text { of } \mathrm{CRM}^{\mathrm{a}}(=3500 \mathrm{t} \\
-145 \mathrm{t} / \mathrm{h} \times 8 \mathrm{~h})\end{array}$ \\
\hline Second stage pre-heater (no.) & 1 & - & - & - & $\begin{array}{l}\text { Increases the } \mathrm{CRM}^{\mathrm{a}} \text { temperature to } \\
800^{\circ} \mathrm{C}\end{array}$ \\
\hline Conventional calciner (no.) & - & 1 & 1 & 1 & Existing calciner (3500 t/day) \\
\hline
\end{tabular}




\subsubsection{Heliostats}

Heliostats have a concrete foundation, a supporting metal structure and a composite mirror (formed of 32 facets). The facets are manufactured using a layered structure of glass, silver and copper, coated for protection. A hydraulic mechanism allows the mirror to rotate and incline according to the sun's position (Kelly 2010). Materials, land area and services necessary for the construction of a heliostat are listed in Table 2.

ASUP 140 heliostats with a surface area of $140 \mathrm{~m}^{2}$ and design comparable to that described by Kelly et al. (2010) are considered for the solar field. Placement of the heliostats in the solar field is designed to provide a homogeneous flux on the reactor and minimise shadowing between heliostats, which would reduce the field's efficiency (Al-Rabghi and Elsayed 1991, Barberena et al. 2016, Wang et al. 2019).

The number of heliostats in the solar field for the three scenarios (see Table 1) has been estimated according to an average daily insolation level of $4.94 \mathrm{kWh} / \mathrm{m}^{2} \cdot$ day $\left(1800 \mathrm{kWh} / \mathrm{m}^{2} \cdot \mathrm{yr}\right)$ in Alicante, a field efficiency of approximately $60 \%$ and a reactor energy efficiency of $80 \%$ (Collado 2008, Besarati and Yogi Goswami 2014).

Table 2 Inventory data for the construction of a heliostat

\begin{tabular}{|c|c|c|c|}
\hline Item & Amount $^{a}$ & $\begin{array}{l}\text { Unit } \\
\text { (per heliostat) }\end{array}$ & Comments $^{b}$ \\
\hline Steel & 3.7 & t & $\begin{array}{l}\text { Low-alloyed and non-alloyed steel } \\
\text { production, extrusion of steel, hot } 1 \text { stroke } \\
\text { and zinc coating are considered for the } \\
\text { manufacture of the steel structure }\end{array}$ \\
\hline Mirrors & 1 & $\mathrm{t}$ & $\begin{array}{l}\text { Coated flat glass, copper, silver and sheet } \\
\text { rolling are considered for the manufacture of } \\
\text { the facets }\end{array}$ \\
\hline Hydraulic oil & 60.2 & $\mathrm{~L}$ & \\
\hline Electronics & 26 & $\mathrm{~kg}$ & Cabling and other electronic components \\
\hline Concrete & 9 & $\mathrm{~m}^{3}$ & \\
\hline Land & 278 & $\mathrm{~m}^{2}$ & \\
\hline Transport & 478 & $\mathrm{t} \cdot \mathrm{km}$ & Truck (32 t) \\
\hline
\end{tabular}

(2019)

b Source: Ecoinvent 3.5 (Wernet et al. 2016).

\subsubsection{Receiver tower}

A receiver tower of optical height of $120 \mathrm{~m}$ is deemed suitable for all scenarios considered as it allows directing the solar beam towards the reactor without obstruction from the inner rows of heliostats (Lopez 2019). Inventory data for the construction of the tower are reported in Table 3.

Table 3 Inventory data for the construction of the receiver tower

\begin{tabular}{lll}
\hline Item $^{\text {a }}$ & Amount $^{\text {b }}$ & Unit (per tower) \\
\hline Lightweight concrete & 728 & $\mathrm{~m}^{3}$ \\
Concrete & 6008 & $\mathrm{~m}^{3}$ \\
Steel B50 & 584 & $\mathrm{t}$ \\
Excavation & 8300 & $\mathrm{~m}^{3}$ \\
Transport (32 t truck) & 58,395 & $\mathrm{t} \cdot \mathrm{km}$ \\
\hline
\end{tabular}

a Source: Ecoinvent 3.5 (Wernet et al. 2016).

b Source: Personal communication (Lopez 2019).

\subsubsection{Solar calciner}

As shown in Figure 3, the solar calciner (reactor) is located on top of the receiver tower and gets irradiated by the concentrated solar beam produced by the solar field. Fluidised bed reactor is considered for all solar systems with raw materials fluidised by an air flow (Bellan et al. 2019). Fluidised particles flow into the receiver tube, where the concentrated solar flux provides the thermal energy necessary for the calcination of CRM. The reactor is inserted in a cavity made of ceramic fibres which limits the heat dispersion, allowing an energy efficiency of about $80 \%$. 
Table 4 provides inventory data for the construction of the solar reactors in the three scenarios considered in the study. These have been estimated by scaling-up a pilot-scale reactor, considering the desired capacity and the required surface area given in Table 1 (SOLPART 2019).

The reactor's irradiated surface area is composed of alloy $800 \mathrm{H}$. The size of the irradiated surface for the reactors in the three scenarios (Table 1) has been estimated according to the reactors' capacity (438, 145 and $63 \mathrm{t} / \mathrm{h}$ for the full solar, hybrid 1 and hybrid 2 scenarios, respectively). Common austenitic stainless steel (304L) is considered for the construction of the reactor's body. Other types of austenitic stainless steel, including steel 316 and 1.4845, are also used for the construction of the reactor. It should be noted that life cycle inventory data for some of the alloys are not available in LCA databases and therefore they have been modelled using similar manufacturing processes available in Ecoinvent 3.5 by modifying the material composition. For further details, see Table 4.

Table 4 Inventory data for the construction of a solar calciner (reactor) in the three scenarios considered in the study

\begin{tabular}{|c|c|c|c|c|c|}
\hline Item $^{a}$ & Full solar ${ }^{b}$ & $\begin{array}{l}\text { Hybrid } 1 \\
\text { (33\% solar) }^{b}\end{array}$ & $\begin{array}{l}\text { Hybrid } 2 \\
\left(^{14 \% \text { solar })^{b}}\right.\end{array}$ & $\begin{array}{l}\text { Unit } \\
\text { (per reactor) }\end{array}$ & Comments \\
\hline Alloy $800 \mathrm{H}$ & 21.3 & 10.5 & 4.5 & $\mathrm{t}$ & \\
\hline Steel 304L & 101 & 49.6 & 21.3 & $\mathrm{t}$ & \\
\hline Steel 316 & 144 & 70.8 & 30.3 & $\mathrm{~kg}$ & $\begin{array}{l}\text { Average composition: } 16- \\
18 \% \mathrm{Cr}, 10-14 \% \mathrm{Ni}, 2-3 \% \\
\mathrm{Mo} \text {, traces of } \mathrm{Si}, \mathrm{P}, \mathrm{S}, \mathrm{Ti} \\
\text { and Fe to balance; based } \\
\text { on the production of } \\
\text { chromium steel }(18 / 8)\end{array}$ \\
\hline Steel 1.4845 & 30.8 & 15.1 & 6.5 & $\mathrm{~kg}$ & $\begin{array}{l}\text { Average composition: 15.5- } \\
17.5 \% \mathrm{Cr}, 15.5-17.5 \% \mathrm{Ni} \text {, } \\
2.5-3.5 \% \mathrm{~W}, 1.5 \% \text { (max) } \\
\mathrm{Mn}, 1.2 \% \text { (max) Nb, traces } \\
\text { of } \mathrm{C}, \mathrm{Si}, \mathrm{P}, \mathrm{S}, \mathrm{N} \text { and Fe to } \\
\text { balance; based on the } \\
\text { production of chromium } \\
\text { steel (18/8) }\end{array}$ \\
\hline Graphite & 33.2 & 16.4 & 7 & $\mathrm{~kg}$ & \\
\hline $\begin{array}{l}\text { Ceramic } \\
\text { fibres }\end{array}$ & 648 & 319 & 137 & $t$ & \\
\hline Transport & 77,760 & 38,304 & 16,416 & $\mathrm{t} \cdot \mathrm{km}$ & Truck (32 t) \\
\hline
\end{tabular}

${ }^{a}$ Source: Ecoinvent 3.5 (Wernet et al. 2016).

b Source: SOLPART project (SOLPART 2019).

\subsubsection{Hot storage units}

As mentioned earlier, in the full solar scenario, the solar reactor is designed to produce its daily output of $3500 \mathrm{t}$ of calcined CRM in $8 \mathrm{~h}$ (daylight) of operation. Therefore, to allow the cement plant to operate continuously $24 \mathrm{~h} /$ day, two storage units, each able to contain the daily capacity of the solar calciner, and a second stage pre-heater used for heat recovery from the solar calciner, are required (Figure 3). Table 5 provides data for the construction of these components, estimated by scaling-up pilot-scale components based on the volume of material to be processed (SOLPART 2019).

Table 5 Inventory data for the construction of hot storage and second-stage pre-heater

\begin{tabular}{lll}
\hline Item $^{\text {a }}$ & Amount $^{\text {b }}$ & Unit \\
\hline Steel 304L & 710 & $\mathrm{t}$ \\
Carbon steel & 48 & $\mathrm{t}$ \\
Ceramic fibres & 177 & $\mathrm{t}$ \\
Transport (32 t truck) & 75,741 & $\mathrm{t} \cdot \mathrm{km}$ \\
\hline a Source: Ecoinvent 3.5 (Wernet et al. 2016). \\
b Source: SOLPART project (SOLPART 2019).
\end{tabular}




\subsubsection{Operation of calciners}

Operational data for the production of 3500 t/day of calcined CRM are provided in Table 6 and Table 7. The thermal heat and electricity requirements for the conventional calciner are estimated at 3.15 and $0.21 \mathrm{GJ} / \mathrm{t}$ calcined CRM, respectively (García-Gusano et al. 2014). The thermal energy requirements have been determined according to the heat of dissociation of limestone $(3.18 \mathrm{GJ} / \mathrm{t}$ $\mathrm{CaO}$ at $25^{\circ} \mathrm{C}$ ), the energy required to heat the CRM to about $900^{\circ} \mathrm{C}$ and the energy efficiency of the conventional system of $50 \%$ (Meier et al. 2005). In accordance with the existing cement plant in Alicante, petroleum coke has been selected as fuel for the conventional calciner. Its consumption has been estimated based on a gross calorific value of $33.5 \mathrm{MJ} / \mathrm{kg}$ of petroleum coke.

Table 6 Inventory data for the operation of solar and conventional calciners

\begin{tabular}{|c|c|c|c|c|c|c|}
\hline Item $^{\text {a }}$ & $\begin{array}{l}\text { Full solar } \\
(100 \% \\
\text { solar) }\end{array}$ & $\begin{array}{l}\text { Hybrid } 1 \\
\text { (33\% } \\
\text { solar) }\end{array}$ & $\begin{array}{l}\text { Hybrid } 2 \\
\text { (14\% } \\
\text { solar) }\end{array}$ & $\begin{array}{l}\text { Conven- } \\
\text { tional }\end{array}$ & $\begin{array}{l}\text { Unit (per } \\
\text { functional } \\
\text { unit) }^{b}\end{array}$ & Reference \\
\hline Limestone & 863 & 863 & 863 & 863 & $\mathrm{~kg}$ & Garcia Garcia (2019) \\
\hline Marl & 663 & 663 & 663 & 663 & $\mathrm{~kg}$ & Garcia Garcia (2019) \\
\hline Sand & 15 & 15 & 15 & 15 & $\mathrm{~kg}$ & Garcia Garcia (2019) \\
\hline Petroleum coke & - & 60 & 77 & 94 & $\mathrm{~kg}$ & SOLPART (2019) \\
\hline Electricity & 58 & 161 & 207 & 209 & MJ & Garcia Garcia (2019) \\
\hline Compressed air & 88 & 42 & 21 & - & $m^{3}$ & $\begin{array}{l}\text { Richardson et al. } \\
\text { (2002) }\end{array}$ \\
\hline Water & 17 & 5 & 2 & - & $\mathrm{L}$ & Lopez (2019) \\
\hline Mirror & 25 & 7 & 3 & - & $\mathrm{g}$ & Lopez (2019) \\
\hline Diesel (cleaning truck) & 64 & 17 & 7 & - & $g$ & $\begin{array}{l}\text { Johnston (2018), } \\
\text { SCARAB-FAYAT } \\
\text { (2019) }\end{array}$ \\
\hline
\end{tabular}

${ }^{\text {a }}$ Life cycle inventory data sourced from Ecoinvent 3.5 (Wernet et al. 2016).

$\mathrm{b}$ The functional unit is the production of $1 \mathrm{t}$ of calcined cement raw meal.

The amount of fluidisation air used in the fluidised-bed calciner has been determined according to the CRM flow rates in the three scenarios (Richardson et al. 2002). Electricity is mainly utilised for milling operations in conventional calcination. Moreover, electricity required by the solar field, to lift CRM to the top of the tower and to produce compressed air for fluidisation in the reactor are also considered for the solar scenarios. Electricity sourced from the Spanish grid has been considered for all the scenarios (REE 2019) and its impacts have been modelled in Gabi using the background data from Ecoinvent (Wernet et al. 2016); for details, see Table S1 and Figure S1 in Supplementary Information (SI). As indicated in Table 6, the full solar system requires $72 \%$ less electricity than the conventional because of the reduced use of the fuel mill.

Based on experience of existing large-scale solar thermal installations (Lopez 2019), each heliostat requires around $840 \mathrm{kWh} / \mathrm{yr}$ of electricity to change its orientation during the day. Moreover, heliostats would require regular washing by water to remove dust, estimated at $3640 \mathrm{~L} / \mathrm{heliostat}$ annually. A vehicle is used for the washing, with the diesel consumption estimated based on a street cleaning truck (Johnston 2018, SCARAB-FAYAT 2019). A mirror replacement rate of $0.5 \%$ per year has also been considered as part of routine maintenance.

\subsubsection{End-of-life waste management}

For the end-of-life management of solar facilities, $75 \%$ steel recycling rate with a recycling efficiency of $90 \%$ is assumed based on average European data (Sansom 2013). A recycling rate of $50 \%$ has been adopted for refractory and insulating materials and $70 \%$ for concrete according to the targets set by the European Commission's Waste Framework Directive 2008/98/EC (EU 2008). The heliostat components are assumed to be recycled at the same rate as steel and concrete. A recycling rate of $73 \%$ is considered for the mirrors, according to average European data (EU 2019). 
Table 7 Inventory data for petroleum coke and alternative fuels

\begin{tabular}{|c|c|c|c|c|c|c|}
\hline Item & $\begin{array}{l}\text { Petroleum } \\
\text { coke }^{\mathrm{a}}\end{array}$ & MSW $^{\mathbf{a}}$ & TDF $^{a}$ & Waste oila & $\begin{array}{l}\text { Waste } \\
\text { solvents }\end{array}$ & $\begin{array}{l}\text { Unit (per } \\
\text { functional unit)b }\end{array}$ \\
\hline Calorific value & 34 & 17 & 32 & 36 & 25 & $\mathrm{MJ} / \mathrm{kg}$ fuel \\
\hline Amount & 94 & 185 & 98 & 87 & 126 & $\mathrm{~kg}$ \\
\hline Transport & 9.4 & 18.5 & 9.8 & 8.7 & 12.6 & $\mathrm{t} \cdot \mathrm{km}$ \\
\hline Ammonia & 22.8 & $14.9 \times 10^{-3}$ & 119 & 155 & n.d. & g \\
\hline Antimony & 2.0 & 211 & $3.5 \times 10^{-2}$ & n.d. ${ }^{c}$ & n.d. & $\mathrm{mg}$ \\
\hline Arsenic & 26.5 & 1.45 & 98.3 & 0.1 & $2.5 \times 10^{-2}$ & $\mathrm{mg}$ \\
\hline Beryllium & 3.0 & 54.1 & n.d. & 191 & n.d. & $\mathrm{mg}$ \\
\hline Cadmium & 8.0 & 127 & 795 & 3.7 & $1.2 \times 10^{-2}$ & $\mathrm{mg}$ \\
\hline Carbon dioxide & 318 & 88.4 & 306 & 246 & 219 & $\mathrm{~kg}$ \\
\hline Carbon monoxide & 1.5 & $1.1 \times 10^{-2}$ & 0.1 & $1.0 \times 10^{-3}$ & n.d. & $\mathrm{kg}$ \\
\hline Chromium & 41.0 & 4.0 & 3.4 & 51.9 & $2.4 \times 10^{-2}$ & $\mathrm{mg}$ \\
\hline Copper & 65.0 & 8.5 & 0 & 0.3 & $5.1 \times 10^{-2}$ & $\mathrm{mg}$ \\
\hline Hydrogen chloride & 6.3 & 0.6 & 202 & 1.0 & 3.0 & $\mathrm{~g}$ \\
\hline Lead & 98.0 & 3.8 & 105 & 285 & 0.7 & $\mathrm{mg}$ \\
\hline Mercury & 8.9 & 3.4 & 9.9 & 0 & 3.1 & $\mathrm{mg}$ \\
\hline Nickel & 49 & 1.9 & 1.8 & 1.3 & 2.6 & $\mathrm{mg}$ \\
\hline Nitrogen oxides & 1.2 & $4.7 \times 10^{-2}$ & $3.8 \times 10^{-2}$ & 0.1 & $2.0 \times 10^{-2}$ & $\mathrm{~kg}$ \\
\hline Volatile organic compounds & 18 & 0.3 & $4.1 \times 10^{-2}$ & 12.9 & n.d. & $g$ \\
\hline Dioxins & $4.1 \times 10^{-3}$ & 35.9 & 2.9 & 778 & n.d. & $\mathrm{mg}$ \\
\hline Selenium & 25.3 & 0.4 & 0.1 & n.d. & n.d. & $\mathrm{mg}$ \\
\hline Sulphur dioxide & 0.4 & $2.8 \times 10^{-3}$ & 2.6 & $3.7 \times 10^{-8}$ & 1.7 & $\mathrm{~kg}$ \\
\hline Thallium & 13 & n.d. & n.d. & 42.6 & 1.8 & $\mathrm{mg}$ \\
\hline Tin & 9 & $9.1 \times 10^{-3}$ & n.d. & 141 & n.d. & $\mathrm{mg}$ \\
\hline Vanadium & 5 & 6.5 & n.d. & 7.3 & n.d. & $\mathrm{mg}$ \\
\hline Zinc & 424 & 104 & 145 & 152 & 140 & $\mathrm{mg}$ \\
\hline
\end{tabular}

a All emission data represent averages obtained from the following sources: petroleum coke (Zemba et al. 2011, EMEP/EEA 2013, Georgiopoulou and Lyberatos 2018); MSW (Güereca et al. 2015, Panahandeh et al. 2017, Georgiopoulou and Lyberatos 2018); TDF (Kääntee et al. 2004, Georgiopoulou and Lyberatos 2018); waste oils (Berry and MacDonald 1975, Aul and Peechan 1993, Boughton and Horvath 2004); solvents (Seyler et al. 2004).

${ }^{b}$ All data are expressed per functional unit of $1 \mathrm{t}$ of calcined cement raw meal, except the calorific value, which is expressed per $\mathrm{kg}$ of fuel.

${ }^{c}$ n.d.: Not detected.

Ecoinvent 3.5 data have been used to model the recycling processes and the system has been credited for recycling of virgin materials via system expansion. Specifically, for steel products, a recycled content of $30 \%$ is assumed and, therefore, at the end of life, $70 \%$ of the steel sent for recycling has been credited to the system (SRI 2009, Broadbent 2016). According to Ecoinvent data (Wernet et al. 2016), no recycled content is assumed for other material considered.

A generic distance of $100 \mathrm{~km}$ from the landfill site or from the recycling plant is assumed for all materials.

\subsubsection{Improvement opportunities}

To accomplish the second goal of the study, the following improvement options are considered: improved solar field efficiency, use of solar photovoltaics (PV) for calcination instead of grid electricity, utilisation of alternative fuels instead of petroleum coke and integration of CCS into the cement plant. The first two options are selected based on the hotspot analysis discussed later in the paper. The use of waste as an alternative calcination fuel is chosen for evaluation to reflect its growing utilisation in cement production globally. Finally, integrating CCS into the cement production is compared with the solar system to find out which of the two options offers a greater potential for reducing the impacts from this sector. To determine the highest possible improvements, only the full solar system is considered in all relevant cases detailed below.

\subsubsection{Solar field efficiency and solar PV}

Technological improvements and more efficient placement can increase the efficiency of the solar field and so reduce the number of heliostats. For this assessment, the field efficiency of the full 
solar system is assumed to increase from $60 \%$ to $70 \%$. In that case, the number of heliostats would decrease from 4910 to 4174.

Electricity is used mainly for milling operations and replacing grid electricity by solar PV could potentially reduce the impacts from this process. Solar PV is selected for consideration because locations suitable for the solar thermal system would also provide optimal conditions for solar PV. Only the full solar system is evaluated, assuming open ground PV installation in Spain, with the LCA data sourced from Ecoinvent (Wernet et al. 2016).

\subsubsection{Alternative calcination fuels}

As the use of alternative fuels for cement production is a well-established practice (Rahman et al. 2015, Bourtsalas et al. 2018), the four most common alternatives are also considered: municipal solid waste (MSW), waste oil, waste solvents and tyre-derived fuel (TDF). A 100\% substitution by each of these fuels is evaluated in turn, as the feasibility of such practice has already been demonstrated (Albino et al. 2011, Zieri and Ismail 2018). The amount of alternative fuels required for replacing petroleum coke has been estimated based on the above-mentioned energy requirements. The composition of the fuels and the emissions of pollutants are based on literature data (Kääntee et al. 2004, Richards and Agranovski 2015, Georgiopoulou and Lyberatos 2018). These are detailed in Table 7, together with the fuels' calorific values. The transport distance is assumed at $100 \mathrm{~km}$ for all fuels considered.

\subsubsection{Carbon capture and storage}

Post-combustion CCS with chemical absorption currently represents the most proven technology (Gruenewald and Radnjanski 2016). Moreover, pilot trials and industrial scale demonstration plants have been carried out by the cement industry (CSI-ECRA 2017). Thus, post-combustion CCS has been selected for evaluation here with the process steps outlined in Figure 4. As indicated, $\mathrm{CO}_{2}$ is captured by absorption in monoethanolammine (MEA). It is assumed that $80 \%$ of the total $\mathrm{CO}_{2}$ emitted from the calciner is captured (IEA 2008, Schakel et al. 2018). The MEA is regenerated in a stripper, utilising a steam reboiler, after which it is separated from $\mathrm{CO}_{2}$ and water in a condenser. The regenerated MEA is recycled back into the process; based on the literature (García-Gusano et al. 2015), it is assumed that $99.5 \%$ of solvent is recovered and reused and the rest is topped-up. The concentrated $\mathrm{CO}_{2}$ stream is compressed, ready for storage; the latter is not considered here but compression is included (Figure 4). A combined heat and power (CHP) plant utilising natural gas is used to supply the electricity and heat required by the CCS plant. The materials and energy requirements are summarised in Table 8, based on data for post-combustion CCS in the cement industry in Spain (García-Gusano et al. 2015). For simplicity, the same data and assumptions are used for both the conventional and solar CCS, although the latter would not require ammonia and limestone for removal of $\mathrm{NOx}$ and $\mathrm{SO}_{2}$ from combustion gases as no fuel is used in this system.

The total amount of $\mathrm{CO}_{2}$ emitted from the conventional calciner is estimated at $669 \mathrm{~kg} \mathrm{CO} / \mathrm{t}$ calcined CRM, comprising $351 \mathrm{~kg} \mathrm{CO} / \mathrm{t}$ generated during limestone calcination (based on the stoichiometry) and $318 \mathrm{~kg} \mathrm{CO} / \mathrm{t}$ released by combustion of petroleum coke (Table 7). By inference, the full solar system emits in total $351 \mathrm{~kg} \mathrm{CO} / \mathrm{t}$ (calcination only, as there is no petroleum coke). Therefore, based on the $80 \%$ capture efficiency, $535 \mathrm{~kg} \mathrm{CO} / \mathrm{t}$ calcined $\mathrm{CRM}$ is removed from the conventional and $281 \mathrm{~kg} \mathrm{CO}_{2} / \mathrm{t}$ from the solar calciner.

Table 8 Inventory data for the operation of the post-combustion CCS system

\begin{tabular}{|c|c|c|}
\hline Item $^{\mathbf{a}}$ & Amount $^{b}$ & Unit \\
\hline Monoethanolamine (MEA) & 1.6 & $\mathrm{~g} / \mathrm{kg} \mathrm{CO} 2$ \\
\hline Ammoniac & 3.3 & $\mathrm{~g} / \mathrm{kg} \mathrm{CO} 2$ \\
\hline Limestone $^{d}$ & 23 & $\mathrm{~g} / \mathrm{kg} \mathrm{CO} 2$ \\
\hline Heat & 4.1 & $\mathrm{MJ} / \mathrm{kg} \mathrm{CO} 2$ \\
\hline Electricity & 0.15 & $\mathrm{kWh} / \mathrm{kg} \mathrm{CO} 2$ \\
\hline \multicolumn{3}{|c|}{$\begin{array}{l}\text { a Life cycle inventory data sourced from Ecoinvent } 3.5 \text { (Wernet et al. 2016). } \\
\text { b Literature data (UNIDO 2010, García-Gusano et al. 2015). } \\
\text { c Used for selective catalytic reduction to remove NOx. }\end{array}$} \\
\hline
\end{tabular}




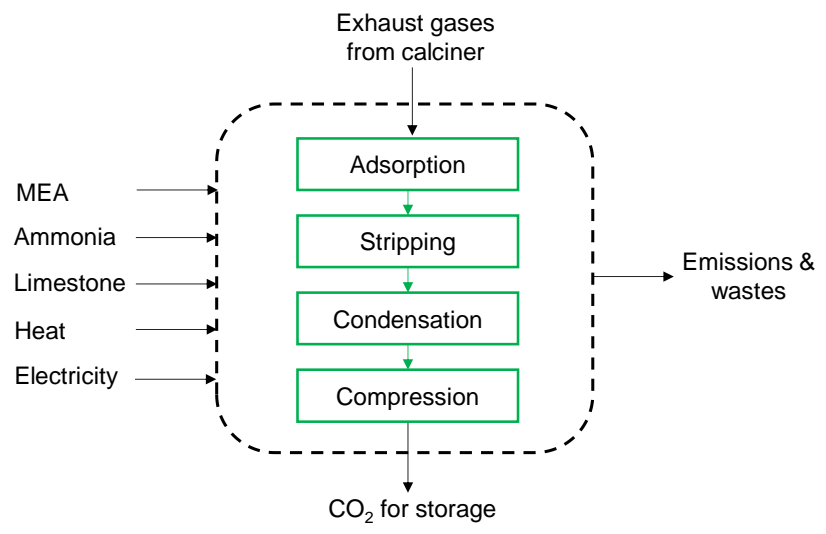

Figure 4 System boundaries for post-combustion carbon capture [MEA: monoethanolamine].

\subsubsection{Global implications}

Insolation levels suitable for installation of the solar calcination system, measured by direct normal irradiation (DNI), are reported in large areas of the American continent, Africa, Australia, Middleeast and Asia (Solargis 2016). However, to determine the potential dispatchability of solar cement plants, it is necessary to consider the cement production capacity and the DNI of the considered country/region. Table 9 shows the percentage of global cement production in various regions in 2018 (CEMBUREAU 2018, USGS 2019), alongside the percentage of land area with a DNI exceeding $1800 \mathrm{kWh} / \mathrm{m}^{2} \cdot \mathrm{yr}$. The latter has been selected here as the minimum insolation level to correspond to that of Alicante considered in this study (Janjai et al. 2011, Solargis 2016).

As shown in Table 9, over $56 \%$ of global cement production is located in China, which is by far the largest producer of cement in the world (CEMBUREAU 2018, USGS 2019). Suitable DNI levels are found in various areas of China and especially in the south-western region. Overall, about $23 \%$ of Chinese land area is suitable for the installation of the solar thermal technology. Large suitable areas (53\%) are also estimated for the rest of Asia and the American continent (29\% on average). Assuming an even distribution of cement production across each country and considering the suitable areas for solar cement production (Table 9), it is estimated here that the solar thermal technology could be applied to about $26 \%$ of global cement production using a minimum DNI value of $1800 \mathrm{kWh} / \mathrm{m}^{2} \cdot \mathrm{yr}$.

The mix of fossil fuels considered for conventional calcination comprises petroleum coke (34\%), hard coal $(31 \%)$, fuel oil $(22 \%)$ and natural gas $(<1 \%)$ (Wernet et al. 2016). An average total substitution rate of fossil fuels of $13 \%$ is assumed at the global scale (Hasanbeigi et al. 2012), considering the alternative fuels used worldwide, i.e. MSW, waste oil, waste solvents and TDF, with an equal share of each (3.25\%). Note that these are the same alternative fuels considered for the improvement opportunity discussed in Section 3.2.5.2.

Table 9 Suitable areas for solar technology and cement production capacity by region

\begin{tabular}{lll}
\hline Country/region & Production capacity (\%) & $\begin{array}{l}\text { a } \\
\mathbf{k W h} / \mathbf{m}^{\mathbf{2}} \mathbf{y r} \mathbf{y r}(\%)^{\mathbf{b}}\end{array}$ \\
\hline Africa & 5.0 & 7 \\
America (excl. USA) & 4.6 & 26 \\
Asia (excl. China, India, Russia) & 14.5 & 53 \\
China & 56.5 & 23 \\
Europe & 6.3 & 5 \\
India & 6.8 & 10 \\
Russia & 1.3 & 1 \\
Turkey & 2.0 & 76 \\
USA & 2.3 & 37 \\
Others & 0.6 & 81 \\
\hline a Relative to a global cement production capacity of 4.1 bn t/yr (CEMBUREAU 2018, USGS 2019). \\
b Estimated as part of this work according to the direct normal irradiation (DNI) level reported by the Global Solar Atlas \\
(Solargis 2016).
\end{tabular}




\subsection{Life cycle impact assessment}

The life cycle impacts have been estimated by applying the ReCiPe 2016 V1.1 impact assessment method at the mid-point level, following the hierarchist approach (Huijbregts et al. 2016).

All 17 impact categories included in this version of ReCiPe are considered, as follows: climate change (CC), particulate matter formation (PMF), freshwater ecotoxicity (FET) and eutrophication (FE), marine ecotoxicity (MET) and eutrophication (ME), human toxicity cancer and non-cancer (HTc and HTnc), ionising radiation (IR), land use (LU), photochemical ozone formation ecosystems and human health (POFe and POFh), ozone depletion potential (ODP), terrestrial acidification (TA) and ecotoxicity (TET), fossil (FD) and metal depletion (MD).

\section{Results and discussion}

The results are discussed first for the functional unit of $1 \mathrm{t}$ of calcined CRM, followed by the impacts at the global level based on annual production of calcined CRM in regions with insolation levels sufficient for solar installations.

\subsection{Impacts per tonne of calcined cement raw meal}

The life cycle impacts of the production of $1 \mathrm{t}$ of calcined CRM via solar and conventional calcination are presented in Figure 5. The results show that, compared to the conventional system, the full solar system can reduce the impacts of the calcination process in 14 out of 17 categories and the hybrid alternatives perform better for up to eight impacts. This is discussed in more detail below.

\subsubsection{Climate change (CC)}

The CC impact of the full solar system is $48 \%$ lower than that of conventional calcination (369 vs $706 \mathrm{~kg} \mathrm{CO} 2$ eq.). Based on the literature (Yang et al. 2017, Cankaya and Pekey 2019), this represents $39-56 \%$ reduction in the impact from the whole cement production process, given that $94 \%$ of $\mathrm{CO}_{2}$ is emitted during calcination. The equivalent reductions for the hybrid 1 and 2 scenarios are more modest ( $15 \%$ and $8 \%$, respectively) compared to conventional calcining.

In the conventional calcination system, the major contributors to $\mathrm{CC}$ are the use of petroleum coke $(47 \%)$ and $\mathrm{CO}_{2}$ emissions from the calcination process $(50 \%)$. Since the use of petroleum coke is avoided in the full solar system, the relative contribution of $\mathrm{CO}_{2}$ from calcination increases to $95 \%$. Therefore, the impact of other stages in this system is small, with the construction of solar facilities and electricity used in the process contributing $2 \%$ each and CRM $1 \%$.

Similar to the conventional system, the main contributors to $\mathrm{CC}$ in the hybrid systems are the use of petroleum coke and $\mathrm{CO}_{2}$ emissions from the calcination process. However, in these systems, the contribution of petroleum coke decreases to $41 \%$ (hybrid 2) and $36 \%$ (hybrid 1) owing to the lower fuel requirements (Table 6).

\subsubsection{Depletion of fossil (FD), metal and mineral (MMD) resources}

FD of conventional calcination is estimated at $29.7 \mathrm{~kg}$ oil eq., the majority of which is caused by petroleum coke (58\%) and electricity (36\%). The use of solar energy reduces this impact by $75 \%$ to $7.5 \mathrm{~kg}$ oil eq. in the full solar scenario. This is due to no fossil fuel being utilised for calcination and its much lower electricity requirements than for the conventional process (Table 6). For the full solar system, most of the FD is caused by electricity (52\%), followed by construction of facilities (27\%) and CRM (20\%).

The reductions in the FD for the hybrids 1 and 2 are $19 \%$ and $6 \%$ compared to the conventional system. Most of the impact in both scenarios is due to petroleum coke (46-50\%) and electricity (36$37 \%)$. 


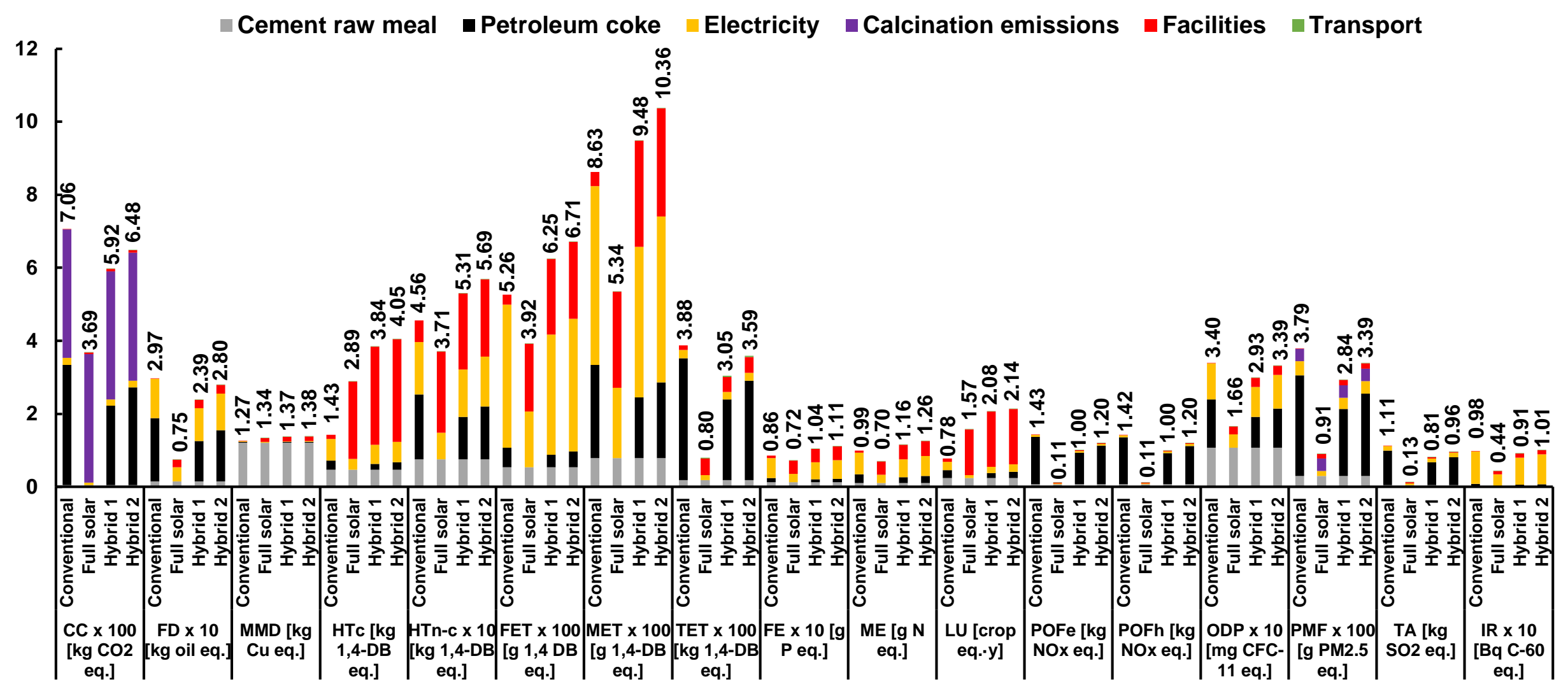

Figure 5 Environmental impacts of solar and conventional calcination systems for different scenarios [All impacts are expressed per tonne of calcined cement raw meal. Calcination emissions in the legend refer to $\mathrm{CO}_{2}$ and particulates. Some impacts have been scaled to fit. To obtain the original values, multiply with the factor on the $\mathrm{x}$-axis, where relevant. CC: climate change; FD: fossil depletion; MMD: metals and minerals depletion; HTc: human toxicity cancer; HTn-c: human toxicity non-cancer; FET: freshwater ecotoxicity; MET: marine ecotoxicity; TET: terrestrial ecotoxicity; FE: freshwater eutrophication; ME: marine eutrophication; LU: land use; POFe: photochemical ozone formation - ecosystems; POFh: photochemical ozone formation - human health; ODP: ozone depletion potential; PMF: particulate matter formation; TA: terrestrial acidification; IR: ionising radiation. DB: dichlorobenzene]. 
Owing to the use of various metals for the construction of solar facilities, the MMD of solar calcination is $6-9 \%$ higher than that of the conventional system. The CRM is the major contributor for both the solar and conventional systems, accounting for $96 \%$ of the total impact of the latter and $88-91 \%$ of the solar systems. This is largely due to the use of marl.

\subsubsection{Human toxicity (HT) and ecotoxicity (FET, MET and TET)}

As can be seen in Figure 5 for the full solar systems, the construction of solar facilities, raw materials and electricity are the main contributors to HT, FET and MET. Consequently, the hybrid options have higher impacts for these categories in comparison to the conventional system. Hybrid 2 is the worst option, with the impacts $20-183 \%$ higher than that of conventional calcination. The full solar has two times higher HT-cancer than the conventional system, but lower HT-non-cancer, FET and MET (19\%, 26\% and 38\%, respectively). These impacts are lower because petroleum coke is not used, while in the conventional system, it contributes respectively $39 \%, 10 \%$ and $30 \%$ to these three categories. Furthermore, less electricity is required in the full solar than in the conventional process.

TET does not follow the above trends because it is mainly caused by petroleum coke (86\%). Thus, this impact is $8-387 \%$ higher for the conventional system compared to the hybrid 2 and full solar scenario, respectively.

\subsubsection{Freshwater and marine eutrophication (FE and ME)}

The FE of the full solar system is $17 \%$ lower than of the conventional (7.2 vs $8.6 \mathrm{~g} \mathrm{P}$ eq.). However, the hybrid options have a $21-29 \%$ higher impact than conventional calcination owing to the additional impact caused by the construction of solar facilities. Hybrid options also have a 17$28 \%$ higher ME than the conventional process. By contrast, a $29 \%$ lower ME is estimated for the full solar system because no fossil fuels are required for its operation. Moreover, the lower electricity requirements of the full solar system (Table 6) balance the higher impact of the solar facilities.

For both freshwater and marine eutrophication, the main hotspots for the solar calcination systems are the electricity and construction of facilities. Most of the construction impacts ( $>95 \%)$ are due to the heliostats (see Figure S2 in the SI). For the full solar system, the contribution of construction is slightly lower than for the hybrid options because of the economy of scale - the higher the capacity of the solar system, the lower the use of the solar field per tonne of calcined CRM.

\subsubsection{Land use}

The heliostats occupy a large land area (278 $\mathrm{m}^{2} /$ heliostat - see Table 2) and are responsible for more than $70 \%$ of land use in the solar calcination scenarios. As a result, the full solar system has twice as high land use as conventional calcination. The hybrid options have even greater land requirements than full solar calcination (167-174\%), again due to the economies of scale.

Although the land use of the full solar system per tonne of CRM is lower compared to the hybrid options, the total land area required for its construction is very significant: $127 \mathrm{ha}$, corresponding to approximately 175 football pitches. By comparison, hybrid 2 requires much less land (28 ha) but still equivalent to around 39 football pitches; for hybrid 1, this number goes up to 92 (67 ha). Thus, land availability could be one of the limiting factors for the development of this emerging technology.

\subsubsection{Photochemical ozone formation (POF) and ozone depletion (ODP)}

Owing to the reduction in the emissions of volatile organic compounds and nitrogen oxides related to the use of petroleum coke, the ecosystem and human health POF impacts of the solar systems are reduced compared to the conventional process. The highest reduction occurs for the full solar scenario (>90\%), followed by hybrid $1(30 \%)$ and hybrid $2(16 \%)$.

Compared to the conventional system, the ODP of the full solar system is $51 \%$ lower. The impact of hybrids 1 and 2 is $12 \%$ and $2 \%$ lower, respectively. These reductions are mainly due to the lower fuel requirements. 


\subsubsection{Particulate matter formation (PMF) and terrestrial acidification (TA)}

As shown in Figure 5, the PMF of the full solar calcination system, estimated at $91 \mathrm{~g} \mathrm{PM}_{2.5}$ eq., is $76 \%$ lower relative to the conventional process. The equivalent reductions for the two hybrid options are $23 \%$ and $11 \%$. These reductions are ascribed to the lower amount of dust generated by the petroleum coke mill, as less or no fuel is consumed by the solar systems (Siqueira-Silva et al. 2016, Khaniabadi et al. 2018).

The solar calcination system also results in a significant reduction in TA owing to the reductions in $\mathrm{SO}_{x}$ and $\mathrm{NO}_{x}$ emissions from the calcination process associated with the combustion of coke. The most significant reductions are found in the full solar system (89\%), while those for hybrids 1 and 2 are $28 \%$ and $14 \%$, respectively.

\subsection{8 lonising radiation (IR)}

The use of nuclear electricity in background processes (e.g., electricity and production of materials) is the main cause of IR. As shown in Figure 5, electricity used in the calcination process accounts for $91 \%$ of the IR for conventional calcination. In the full solar system, the impact is reduced by $55 \%$ owing to lower electricity demand; the reduction for hybrid 1 is much smaller (6\%). However, for hybrid 2, the impact is slightly higher than for the conventional system as the savings from lower electricity demand are counter-balanced by the additional use of electricity in the production of construction materials for the solar facilities. Electricity consumption for the three solar scenarios is mainly related to the milling operations and production of compressed air for the fluidised bed reactor (over $90 \%$ of the total electricity use); the solar field accounts for the rest of electricity demand $(6-10 \%)$.

\subsubsection{Improvement opportunities}

The above analysis shows that the construction of the solar field is the main hotspot for land use and human toxicity-cancer, while electricity consumption is a major contributor to several impacts from the solar calcination systems. Therefore, in this section potential improvement opportunities are explored, focusing on these two areas. As mentioned in Section 3.2.5, the following related options are considered: improved solar field efficiency and use of solar PV in the calcination plant. In addition, the use of waste as a calcination fuel is also considered to reflect its growing utilisation in cement production. Finally, integrating CCS into the cement production is evaluated against the solar option to find out which of the two options offers a greater potential for reducing the impacts from this sector.

\subsubsection{Solar field efficiency}

Figure 6 shows that improving the field efficiency would lead to reductions in HT-cancer and land use of about $4 \%$ relative to the base case. The other impacts would decrease by $1-3 \%$. The CC impact would remain unchanged as the contribution of the solar facilities to this category is negligible $(<2 \%)$.

Conversely, owing to the large amount of dust commonly found in cement plants, it is also possible that the solar field would have a lower efficiency compared to the estimated $60 \%$ (Yadav et al. 2014). If a $50 \%$ field efficiency is considered (5647 heliostats), HT-cancer and land use would increase by $11 \%$ and $12 \%$, respectively, while the other impacts would increase by $2-19 \%$, apart from $\mathrm{CC}$, which would remain the same as $\mathrm{CO}_{2}$ emissions are not influenced by the field's efficiency.

Overall, this analysis shows that varying the number of heliostats within the range considered has relatively small effects on most of the impacts of solar calcination, including land use. Regarding the latter, the land area would decrease from 127 to 116 ha with the efficiency increase from $60 \%$ to $70 \%$. Nevertheless, efficiency improvements might still help to increase the applicability of this technology by decreasing the cost of the solar field, which is affected by the number of heliostats and the land area needed for their construction (Leonardi et al. 2019, Saghafifar et al. 2019). For example, considering a capital cost of a heliostat of about $\$ 200 / \mathrm{m}^{2}$, reducing the number of heliostats from 4910 to 4174 could reduce the cost of the field by about $\$ 21$ million (Blackmon 2013). Moreover, if the target cost of $\$ 75-120 / \mathrm{m}^{2}$ can be achieved the initial investment for the 
construction of the solar field would be lowered further, possibly increasing the applicability of this technology (Coventry et al. 2016).

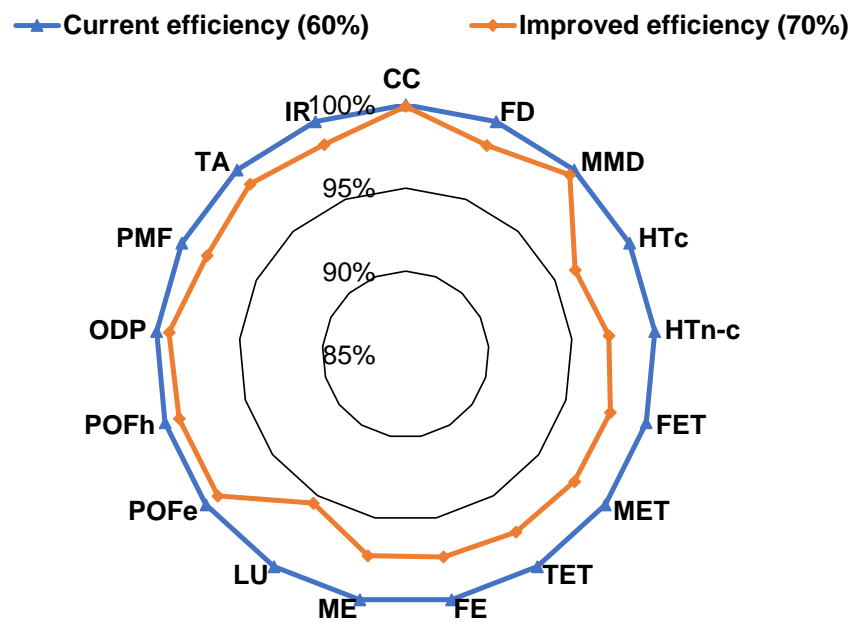

Figure 6 The effect on the impacts of increased solar field efficiency of the full solar system [See Figure 5 for the abbreviations.].

\subsubsection{Solar PV}

As shown in Figure 5, electricity is the main contributor to two impacts from the full solar system: fossil depletion (52\%), and ionising radiation (73\%). Moreover, contributions of $15-39 \%$ are observed in another 12 categories. Therefore, replacing grid electricity with solar PV would reduce these impacts, with the most significant reductions found for ionising radiation $(67 \%)$, fossil depletion (46\%) and terrestrial acidification (31\%) (Figure 7).

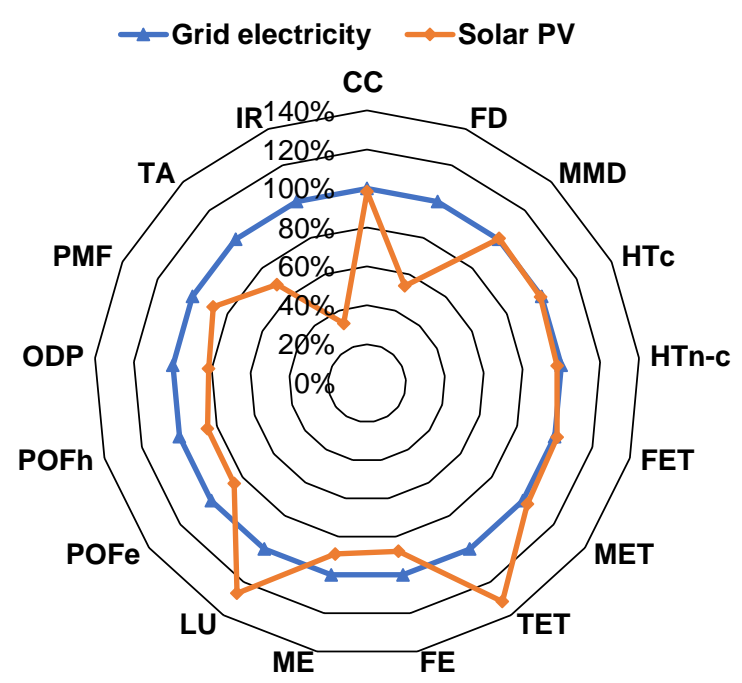

Figure 7 The effect on the impacts of the use of solar PV for electricity in the full solar system [See Figure 5 for the abbreviations.].

However, since the construction of the PV field requires additional materials (e.g. steel, concrete and PV modules) and land (4.7 $\mathrm{m}^{2}$ per $\mathrm{m}^{2}$ of installed modules), this results in increased terrestrial ecotoxicity (32\%) and land use (27\%). Metal depletion, freshwater and marine ecotoxicity are also higher, but the increase is small $(<3 \%)$.

Therefore, it can be seen that coupling the solar thermal system with PV electricity has a potential to reduce further the environmental impacts of calcination. However, additional land required for the construction of the PV field, increased capital expenditure, the intermittence of solar energy 
supply and the low efficiency of solar PV in regions with poor insolation might limit the use of this technology.

\subsubsection{Alternative calcination fuels}

This section considers the environmental implications of substituting petroleum coke with MSW, waste oil, waste solvents or tyre-derived fuel (TDF). The impacts are also compared to the full solar scenario to identify the most environmentally sustainable option for cement production (Figure 8).

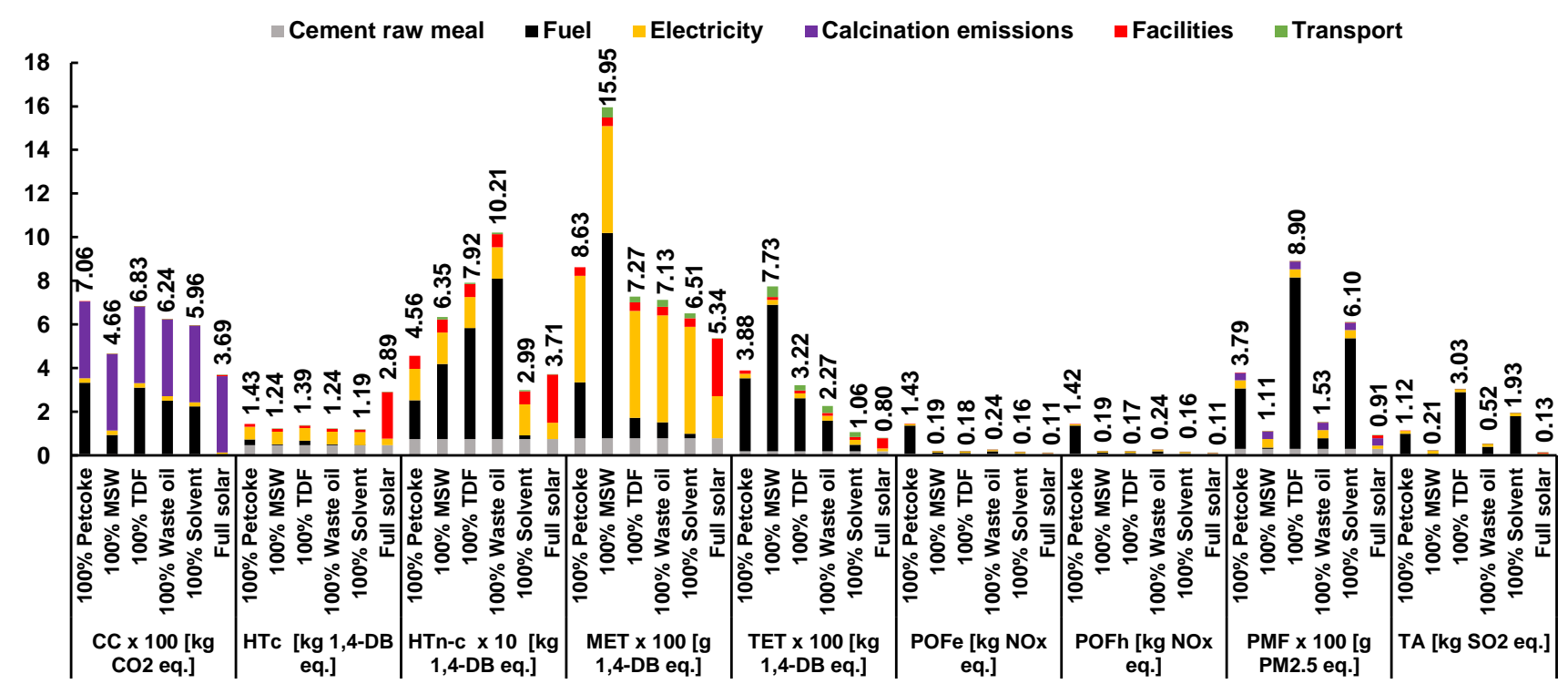

a) Impacts influenced by gaseous emissions from calcination and fuel combustion

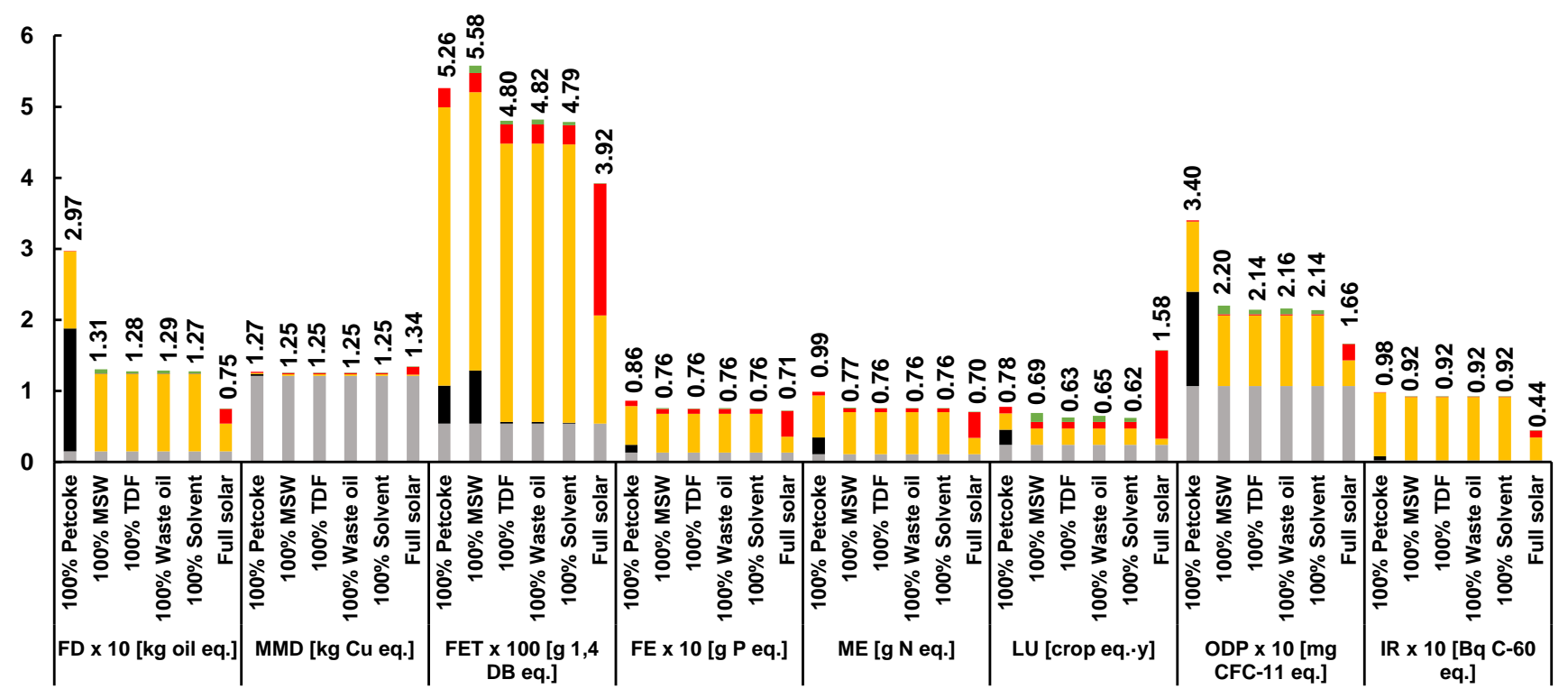

b) Impacts influenced by cement raw meal and electricity

Figure 8 Environmental impacts of alternative fuels used in cement production. [All impacts are expressed per tonne of calcined cement raw meal. Calcination emissions in the legend refer to $\mathrm{CO}_{2}$ and particulates. Some impacts have been scaled to fit. To obtain the original values, multiply with the factor on the $x$-axis, where relevant. See Figure 5 for the abbreviations.].

As indicated in Figure 8a, MSW shows the lowest impact on climate change, with a 34\% reduction compared to the use of petroleum coke. More moderate improvements are achieved by using waste solvents (15\%) and waste oil (12\%), while TDF leads to a minor reduction due to its carbon intensity, which is comparable to that of petroleum coke (Table 7). The lower CC estimated for MSW is due to its biomass content, as biogenic $\mathrm{CO}_{2}$ emissions are not considered (Moora et al. 
2017). However, the solar system is still the best option for climate change, reducing the impact by $48 \%$ and $21 \%$ compared to petroleum coke and MSW, respectively. This is due to the avoidance of fuel use in solar calcination.

The use of alternative fuels also reduces HT-cancer in the range of $3 \%$ (TDF) to $17 \%$ (waste solvents) compared to petroleum coke (Figure 8a). These reductions are mainly related to the lower emissions of various toxic compounds from the combustion of alternative fuels, including volatile organic compounds and heavy metals (Huijbregts et al. 2016). However, HT-non-cancer is from 39\% (MSW) to 124\% (waste oil) higher for the alternative fuels due to the higher emissions of toxic organic and inorganic pollutants (Zemba et al. 2011, Georgiopoulou and Lyberatos 2018, Holt and Berge 2018). Waste solvents represent an exception, reducing the impact by $34 \%$ as a result of lower toxic emissions (Table 7). By comparison, the full solar scenario shows lower HT-noncancer than MSW (41\%), TDF (53\%) and waste oil $(64 \%)$ - this is despite the high impact caused by the construction of solar facilities as it is balanced by the benefits of avoiding fuel use in calcination (Section 4.1.3). However, this effect is not sufficient to reduce HT-cancer from the solar system, which is the worst option with an impact $102 \%$ higher than that of coke and $108-142 \%$ higher than the alternative fuels.

Using MSW leads to greater freshwater, marine and terrestrial ecotoxicity, increasing them by $6 \%$, $85 \%$ and $99 \%$, respectively, compared to petroleum coke (Figure $8 \mathrm{a}$ ). This is due to dioxins, antimony and other heavy metals released during MSW combustion. The other alternative fuels considered show lower ecotoxicity impacts, with waste solvents leading to the highest reductions $(8-73 \%)$ relative to coke. The alternative fuels used in conventional calcination have higher ecotoxicity impacts $(22-870 \%)$ than the full solar system due to the pollutants emitted from combustion of these fuels (Table 7).

As can be inferred from Figure $8 b$, the most significant reductions in impacts when using the alternative fuels are found for the categories where the production and use of coke are significant contributors (Section 4): fossil depletion (56-57\% reduction), ozone depletion (35-37\%) and photochemical oxidants formations (87-89\%). For the categories largely unaffected by fuel emissions, the impacts from petroleum coke and the alternative fuels are comparable, including eutrophication, metals and minerals depletion, land use and ionising radiation. The small differences in these impacts are mainly related to the production of coke.

Overall, utilising petroleum coke shows higher impacts than the alternative fuels in 11 out of 17 impact categories, with the exception of particulate matter formation, terrestrial acidification, toxicity and ecotoxicity-related categories, for which the alternative fuels are less sustainable. Waste solvents have generally lower impacts than the other fuels considered. This is due to the Waste Incineration Directive 2000/76/EC which regulates the use of solvents as a fuel in cement plants with strict limits on emissions (EU 2000). Similarly, MSW shows comparable or lower impacts than the other fuels in most categories considered. This is mainly related to the biomass components in MSW, such as paper, wood and food waste. However, various factors limit the use of large quantities of MSW in cement production, including uncertainty in supply, lower heating value, high inert content, as well as large water and halogen content causing equipment corrosion (Tsiliyannis 2016). Moreover, the emissions of pollutants, including dioxins and metals (e.g. antimony, beryllium and vanadium), are also a cause of concern (Zemba et al. 2011).

In comparison to the alternative fuels, the solar system has lower impacts in most categories, including climate change. The only exceptions are HT-cancer, metal depletion and land use because of the impacts caused by solar facilities. However, the solar system requires major modifications of the cement plant and additional land, while alternative fuels can be utilised after minor modification of the fuel-delivery system. For these reasons, the use of alternative fuels might be considered by the industry as a more practical option for reducing the impacts of cement production in the short term, with a view of deploying the solar system in the medium to longer terms. 


\subsubsection{Carbon capture and storage}

Based on the assumption that $80 \%$ of $\mathrm{CO}_{2}$ emitted from calcination is captured (IEA 2008, Schakel et al. 2018), CCS results in a $63 \%$ reduction in the CC impact from both systems (Figure 9). This also means that coupling conventional calcination with CCS is more efficient in reducing GHG emissions than solar calcination, as the latter reduces the CC impact by $48 \%$, compared to $63 \%$ achieved with CCS. On the other hand, adding CCS to the solar calciner can reduce the impact by a further $48 \%$ relative to conventional calcination with CCS (or $81 \%$ in total, compared to the conventional process without CCS), making this option superior in terms of climate change mitigation.

However, CCS increases all other impacts of calcination (6-268\%) in both the conventional and solar systems. Significant increases are observed in ten out of 17 impact categories, including fossil depletion ( $13 \%$ and $27 \%$ for conventional and solar, respectively), human toxicity-cancer ( $9 \%$ and $35 \%)$ and non-cancer (12\% and $18 \%)$, marine (16\% and $18 \%)$ and terrestrial ecotoxicity $(9 \%$ and $23 \%$ ), marine eutrophication (198\% and $268 \%$ ), photochemical oxidants formation (5\% and $35 \%)$, ozone depletion potential (98\% and $106 \%$ ), and terrestrial acidification ( $5 \%$ and $23 \%)$. This is due to the additional fuels and materials required to operate CCS. Specifically, the CHP plant is the main contributor (50-93\%) to the CCS impacts in 15 out of 17 categories, with the exception of terrestrial ecotoxicity and marine eutrophication, due to the large amount of heat and electricity required by the CCS process (Table 8). For further details on CCS impacts, see Figure S3 in the Sl.

Overall, the solar system is a more effective option than CCS in reducing the impacts from cement production, leading to $31-92 \%$ lower impacts than conventional calcination with CCS. The only exceptions are human toxicity-cancer, land use and metals and minerals depletion which are $50 \%$, $79 \%$ and $1 \%$ higher, respectively, due to the construction of solar facilities - a trend similar to that observed for the systems without CCS (Sections 4.1.2, 4.1.3 and 4.1.5).

It is worth mentioning again that, unlike conventional calcination, the exhaust gases from the solar calciner do not contain pollutants from combustion as no fuel is used. Therefore, only dust removal will be required prior to CCS, reducing the materials and energy that are used for CCS of the conventional system. Consequently, this would reduce further the impacts of CCS used in the solar system. As mentioned earlier, this has not been considered for simplicity.

Thus, the above analysis clearly shows the potential of CCS to decrease the impact of the calcination process on climate change. However, the drawbacks related to the large amount of heat and electricity required by CCS should be considered carefully. Moreover, if the CHP plant utilises hard coal or other carbon-intensive fuels instead of natural gas considered here, the climate change impact of CCS could increase by $78 \%$ compared to that estimated for natural gas (Volkart et al. 2013). Additional investment related to CCS should also be considered as the capital cost of a post-combustion system can amount to $€ 295 \mathrm{M} / \mathrm{Mt} \mathrm{CO}_{2}$ captured per year (CSI-ECRA 2017). This can add $€ 40-70$ per $t$ of $\mathrm{CO}_{2}$ avoided to the expected operational costs ( $€ 19.5$ per $t$ of clinker), increasing cement production costs from $€ 65.6$ to $€ 129.5$ per $t$ of cement (IEA 2008, UNIDO 2010, CSI-ECRA 2017).

\subsubsection{Study limitations}

It is worth highlighting that this work is based on an ex-ante LCA of a novel solar thermal system for the calcination of CRM which is still under development. Although detailed feasibility studies were conducted as part of the SOLPART project, the integration of the solar system in the Alicante cement plant is theoretical. Thus, it is possible that further modification of the solar system will be needed during later stages of development. It is particularly important to mention that operation of the two hot storage units is of critical importance for the solar system as they allow interfacing of solar facilities (operating $8 \mathrm{~h} /$ day) with conventional facilities (operating $24 \mathrm{~h} /$ day). In case that the hot storage cannot be utilised as intended, more extensive modification of the cement plant might be necessary, possibly affecting the impacts of the solar system. Moreover, the effect of dust produced by milling operations on solar facilities should be investigated further as it might affect materials and energy necessary for cleaning and maintenance of solar facilities. The results for some impacts may also differ if the cement plant is situated elsewhere rather than in Spain, due to 
differences in insolation levels and electricity mix. This limitation is addressed to an extent in the next section.

\subsection{Global environmental implications}

As mentioned in Section 3.2.6, it is estimated within this study that $26 \%$ of global conventional calcination could be replaced by the full solar thermal systems. The resulting life cycle impacts are presented in Figure 10, in comparison with the current situation. The results for the current mix of fossil and alternative fuels ( $87 \%$ and $13 \%$, respectively) suggest that solar calcination can reduce the global impacts by $14-24 \%$ in 16 out of 17 categories. The only exception is metals and minerals depletion which increases by $1 \%$ owing to the construction of solar facilities. The impact on climate change is reduced by $15 \%$, saving $513 \mathrm{Mt} \mathrm{CO}_{2}$ eq./yr at a global scale, equivalent to taking about 112 million cars off the road annually ${ }^{1}$. Therefore, the solar system shows the potential to contribute to the long-term decarbonisation goals of the cement industry.

Figure 10 also shows that increasing the substitution of fossil with alternative fuels from $13 \%$ to $100 \%$ would decrease the CC impact of conventional calcination by $33 \%$ compared to the current situation, while the other impacts would be reduced even more significantly (43-86\%) in 12 out of 17 categories. Metals and minerals depletion (1\%) and particulate matter formation (5\%) would also be reduced, but are still comparable to the impacts from the current fuel mix. On the other hand, the use of $100 \%$ alternative fuels would increase terrestrial ecotoxicity (7\%) and acidification $(2 \%)$ compared to the current situation because of the pollutants emitted during their combustion (Section 4.1.9.3). Conversely, the use of $100 \%$ fossil fuels would increase the CC impact by $5 \%$ compared to the current situation. Twelve other impacts would also increase (5-13\%). Metals and minerals depletion, particular matter formation, terrestrial ecotoxicity and acidification would remain largely the same as at present.

If $26 \%$ of conventional calcination were replaced with the solar alternative and coupled with $100 \%$ alternative fuels used in the conventional process, the impact on climate would be reduced by $40 \%$ compared to the current situation. Most other impacts would also improve (15-87\%). Only metals and minerals depletion would go up slightly $(<1 \%)$. Using $100 \%$ fossil fuels in the solar + conventional scenario would also reduce the impacts on the current situation to a smaller extent: CC would be $12 \%$ lower and all other impacts $5-24 \%$ smaller, with the exception of metals and minerals depletion, which would increase by $2 \%$.

It should be noted that the fuel mix considered for global calcination, comprising hard coal, petroleum coke and liquid fuel, leads to higher impacts compared to the use of petroleum coke considered in Section 4. Moreover, the use of alternative fuels can increase the toxicity and ecotoxicity-related impacts compared to fossil fuels. For example, $100 \%$ alternative fuels cause a $3 \%$ and $7 \%$ increase in terrestrial acidification and ecotoxicity, respectively, compared to the conventional mix.

It is also worth considering that country-specific DNI threshold values may vary depending on various factors, including technological improvements and strategies aimed at reducing GHG emissions. Thus, lower DNI values, such as $1300 \mathrm{kWh} / \mathrm{m}^{2} \cdot \mathrm{yr}$, might be considered economically suitable for the future deployment of this technology (Quaschning 2004). In that case, solar calcination could be applied to about $46 \%$ of global cement production, which could potentially reduce the sector's climate change impact by $27-45 \%$ depending on the fuels substitution rate considered, avoiding emissions of $0.9-1.5 \mathrm{Gt} \mathrm{CO}_{2}$ eq./yr. The latter is equivalent to $2.5-4$ times the GHG emissions of the UK in 2018 (Penistone 2019).

However, depending on the geographical location selected, land availability might be one of the factors determining the feasibility of this technology. Therefore, as mentioned earlier, further research aimed at optimising the efficiency of the heliostats and their placement is needed in order to reduce the size of the solar field (Leonardi et al. 2019, Saghafifar et al. 2019).

\footnotetext{
${ }^{1}$ Estimated according to an average car emission of $4.6 \mathrm{t} \mathrm{CO}_{2} / \mathrm{yr}$, assuming a fuel economy of $7.8 \mathrm{~km} / \mathrm{L}$ of petrol and an
} average mileage of $18,500 \mathrm{~km} / \mathrm{yr}(\mathrm{EPA}, 2020)$. 


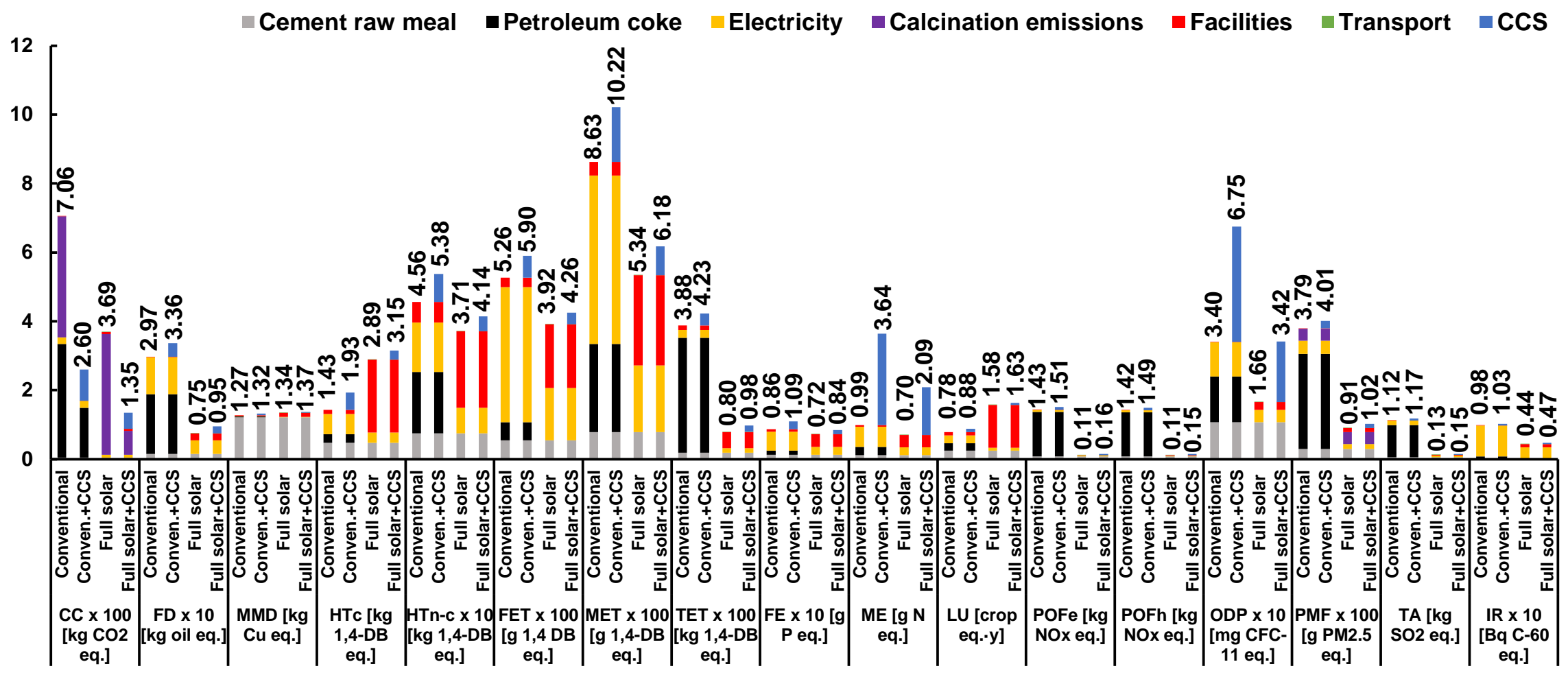

Figure 9 Environmental impacts of conventional and solar calciners with and without carbon capture and storage (CCS) [All impacts are expressed per tonne of calcined cement raw meal. Calcination emissions in the legend refer to $\mathrm{CO}_{2}$ and particulates. Some impacts have been scaled to fit. To obtain the original values, multiply with the factor on the $\mathrm{x}$-axis, where relevant. See Figure 5 for the abbreviations.] 


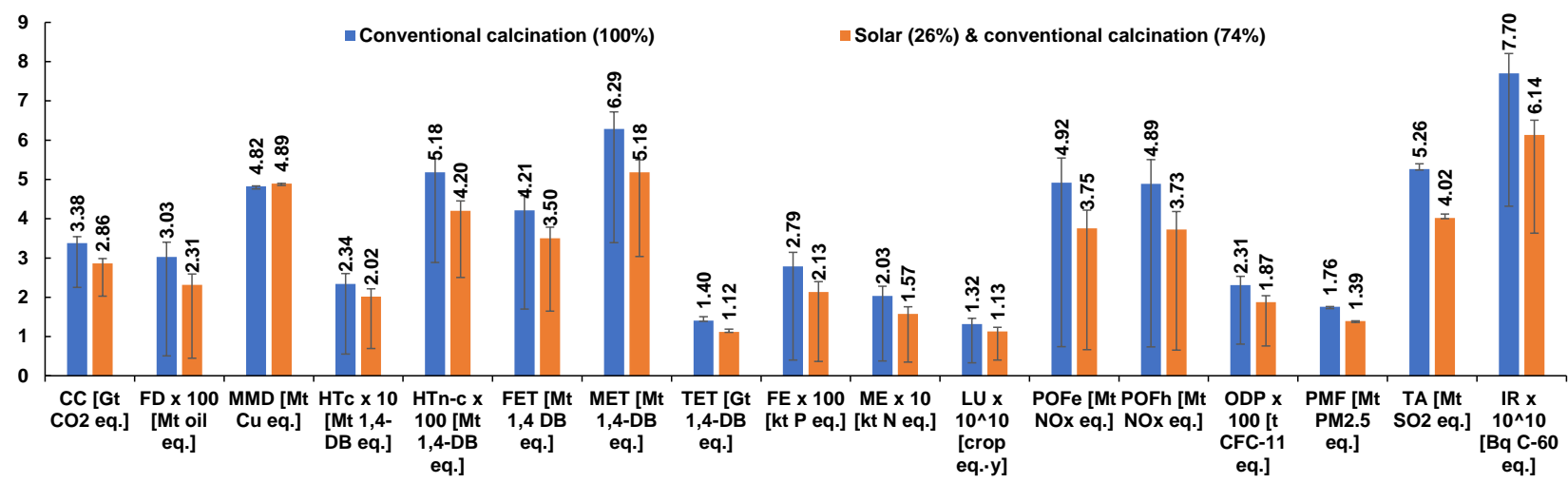

Figure 10 Global environmental implications of replacing $26 \%$ of conventional calcination with the full solar thermal system considering locations with suitable insolation levels [All impacts correspond to the annual production of calcined cement raw meal. The graph bars represent the impacts for the mix of fossil and alternative fuels and the error bars show the range of impacts for $100 \%$ fossil (maximum) and $100 \%$ alternative (minimum) fuels. The exceptions are terrestrial ecotoxicity and acidification for conventional calcination where the opposite applies as they are higher for the alternative fuels. See Figure 5 for the abbreviations.].

\section{Conclusions}

This study has evaluated for the first time the life cycle environmental impacts of cement calcination using solar thermal energy. The results show that replacing the conventional calciner using petroleum coke with the solar system would reduce 14 out of 17 impacts considered. For example, the climate change impact of calcination would be lower by $48 \%$ and depletion of fossil fuels by $75 \%$. The reductions in the other 12 impacts would range from $16 \%$ (freshwater eutrophication) to $92 \%$ (photochemical ozone formation). These reductions are largely due to the avoidance of the usage of petroleum coke in the calcination process. However, the construction of solar facilities, especially heliostats, increases human toxicity-cancer and land use (by 102\% each), as well as metal depletion (6\%), compared to the conventional calcination process.

Partial replacement of conventional calcination would have proportionally lower benefits. For example, if $33 \%$ of CRM was calcined using solar thermal energy, the impacts would be reduced by $6 \%$ (ionising radiation) to $30 \%$ (photochemical oxidants), while the climate change impact would be reduced by $15 \%$.

Increasing the efficiency of the solar field from $60 \%$ to $70 \%$ would lead to relatively small improvements in the impacts of solar calcination. However, decreasing the number of heliostats would reduce the requirements for land and materials needed for the construction of the solar field, which might increase the applicability of the solar technology.

Overall, the use of solar PV could decrease the impacts of the full solar system compared to the use of grid electricity by $1-67 \%$ in 12 impact categories. However, additional land area and materials are necessary for the construction of the PV field, increasing terrestrial ecotoxicity (32\%) and land use (27\%).

The use of $100 \%$ alternative fuels could also reduce significantly the impacts of cement production, reducing the climate change potential by $3 \%$ (waste tyres) to $34 \%$ (municipal solid waste). A further 11 categories would be $1-90 \%$ lower. However, human toxicity and ecotoxicity would be much higher compared to petroleum coke $(39-124 \%$ and $6-99 \%$, respectively). The full solar system is a more environmentally sustainable option compared to the use of alternative fuels in conventional calcination, showing lower impacts in all the categories, with the exception of HT-cancer, metals and minerals depletion and land use. Nevertheless, more significant modifications of the cement plant are necessary to implement the solar system compared to using the alternative fuels.

Coupling with carbon capture shows significant benefits for both conventional and full solar systems, decreasing their climate change impact by 63 and $81 \%$, respectively, compared to the 
conventional scenario. However, additional heat, electricity and materials are required to operate CCS, which increased other impacts compared to the option without CCS (2-198\%). Overall, the solar system might represent a more sustainable option compared to CCS, as it allows lowering the impacts of CRM calcination in 14 categories compared to the conventional process. If the solar thermal systems were implemented at a global level partially replacing conventional calciners $(26 \%$ of the global production), all but one impacts would be reduced by $14 \%$ (human toxicity-cancer) to $24 \%$ (photochemical oxidants formation). The impact on climate change would be $15-40 \%$ lower, depending on the assumed fuel composition. The exception is metals and minerals depletion which would increase by $1 \%$. Using only the alternative fuels instead of the fossil would decrease the impacts by $15-87 \%$, including climate change (40\%).

Therefore, these results suggest that the solar system has a potential to contribute towards the decarbonisation goals established by the cement industry and, through that, to the global climate change mitigation targets. However, it is important to highlight that solar fields require large areas of land for the installation of heliostats and hence the availability of land might be the limiting factor for the development of this technology. Therefore, further research aimed at optimising the efficiency of the heliostats and their placement is needed to reduce the size of the solar field. Future studies should also consider socio-economic costs to determine if allocating a large area of industrial land to the solar field represents a suitable and sustainable investment.

\section{Acknowledgments}

This work was carried out as part of the SOLPART project, funded by the European Union's Horizon 2020 Research and Innovation Programme (Grant agreement No. 654663). The authors gratefully acknowledge this funding. We are also grateful to the SOLPART project partners for data provision and support throughout the project. We would also like to acknowledge Dr Alejandro Gallego-Schmid and Dr Joan Manuel F. Mendoza of the University of Manchester for their valuable comments on an early draft of the manuscript.

\section{References}

Al-Rabghi, O. M. and Elsayed, M. M. Heliostat minimum radial spacing for no blocking and no shadowing condition. Renewable Energy, 1991. 1, 37-47 DOI: https://doi.org/10.1016/09601481(91)90101-T.

Albino, V., Dangelico, R. M., Angelo Natalicchio, A. and Yazan, D. M. (2011). Alternative Energy Sources in Cement Manufacturing: A Systematic Review of the Body of Knowledge, Politecnico di Bari.

An, J., Middleton, R. S. and Li, Y. Environmental Performance Analysis of Cement Production with $\mathrm{CO}_{2}$ Capture and Storage Technology in a Life-Cycle Perspective. Sustainability, 2019. 11, DOI: https://doi.org/10.3390/su11092626.

Aul, E. and Peechan, E. H. (1993). Emission factor documentation for AP-42 SECTION 1.11 Waste oil combustion, EPA office of air quality planning and standards.

AzariJafari, H., Taheri Amiri, M. J., Ashrafian, A., Rasekh, H., Barforooshi, M. J. and Berenjian, J. Ternary blended cement: An eco-friendly alternative to improve resistivity of highperformance self-consolidating concrete against elevated temperature. Journal of Cleaner Production, 2019. 223, 575-586 DOI: https://doi.org/10.1016/i.jclepro.2019.03.054.

Baena-Moreno, F. M., Rodríguez-Galán, M., Vega, F., Alonso-Fariñas, B., Vilches Arenas, L. F. and Navarrete, B. Carbon capture and utilization technologies: a literature review and recent advances. Energy Sources, Part A: Recovery, Utilization, and Environmental Effects, 2018. 41, 1403-1433 DOI: https://doi.org/10.1080/15567036.2018.1548518.

Barberena, J. G., Larrayoz, A. M., Sánchez, M. and Bernardos, A. State-of-the-art of Heliostat Field Layout Algorithms and their Comparison. Energy Procedia, 2016. 93, 31-38 DOI: https://doi.org/10.1016/j.egypro.2016.07.146.

Beccali, M., Cellura, M., Longo, S. and Guarino, F. Solar heating and cooling systems versus conventional systems assisted by photovoltaic: Application of a simplified LCA tool. Solar Energy Materials and Solar Cells, 2016. 156, 92-100 DOI: https://doi.org/10.1016/j.solmat.2016.03.025.

Bellan, S., Kodama, T., Matsubara, K., Gokon, N., Cho, H. S. and Inoue, K. Heat transfer and particulate flow analysis of a $30 \mathrm{~kW}$ directly irradiated solar fluidized bed reactor for 
thermochemical cycling. Chemical Engineering Science, 2019. 203, 511-525 DOI: https://doi.org/10.1016/j.ces.2018.09.012.

Benhelal, E., Zahedi, G., Shamsaei, E. and Bahadori, A. Global strategies and potentials to curb $\mathrm{CO}_{2}$ emissions in cement industry. Journal of Cleaner Production, 2013. 51, 142-161 DOI: https://doi.org/10.1016/j.jclepro.2012.10.049.

Berry, E. E. and MacDonald, L. P. Experimental burning of used automotive crankcase oil in a dryprocess cement kiln. Journal of Hazardous Materials, 1975. 1, 137-156 DOI: https://doi.org/10.1016/0304-3894(75)85004-7.

Besarati, S. M. and Yogi Goswami, D. A computationally efficient method for the design of the heliostat field for solar power tower plant. Renewable Energy, 2014. 69, 226-232 DOI: https://doi.org/10.1016/j.renene.2014.03.043.

Blackmon, J. B. Parametric determination of heliostat minimum cost per unit area. Solar Energy, 2013. 97, 342-349 DOI: https://doi.org/10.1016/j.solener.2013.08.032.

Boughton, B. and Horvath, A. Environmental assessment of used oil management methods. Environ Sci Technol, 2004. 38, 353-358 DOI: https://doi.org/10.1021/es034236p.

Bourtsalas, A. C., Zhang, J., Castaldi, M. J. and Themelis, N. J. Use of non-recycled plastics and paper as alternative fuel in cement production. Journal of Cleaner Production, 2018. 181, 816 DOI: https://doi.org/10.1016/j.jclepro.2018.01.214.

Broadbent, C. Steel's recyclability: demonstrating the benefits of recycling steel to achieve a circular economy. The International Journal of Life Cycle Assessment, 2016. 21, 1658-1665 DOI: https://doi.org/10.1007/s11367-016-1081-1.

Cankaya, S. and Pekey, B. A comparative life cycle assessment for sustainable cement production in Turkey. J Environ Manage, 2019. 249, 109362 DOI: https://doi.org/10.1016/j.jenvman.2019.109362.

CEMBUREAU, The role of cement in the 2050 low carbon economy, 2013.

CEMBUREAU, Activity Report. Brussells, The European Cement Association, 2018, 1-56.

Collado, F. J. Quick evaluation of the annual heliostat field efficiency. Solar Energy, 2008. 82, 379384 DOI: https://doi.org/10.1016/j.solener.2007.10.007.

Comodi, G., Bevilacqua, M., Caresana, F., Pelagalli, L., Venella, P. and Paciarotti, C. LCA Analysis of Renewable Domestic Hot Water Systems with Unglazed and Glazed Solar Thermal Panels. Energy Procedia, 2014. 61, 234-237 DOI: https://doi.org/10.1016/j.egypro.2014.11.1096.

Cormos, C.-C., Cormos, A.-M. and Petrescu, L. Assessing the $\mathrm{CO}_{2}$ Emissions Reduction from Cement Industry by Carbon Capture Technologies: Conceptual Design, Process Integration and Techno-economic and Environmental Analysis. 27th European Symposium on Computer Aided Process Engineering, 2017. 2593-2598 DOI: https://doi.org/10.1016/B978- 0-44463965-3.50434-7.

Corona, B., Ruiz, D. and San Miguel, G. Life Cycle Assessment of a HYSOL Concentrated Solar Power Plant: Analyzing the Effect of Geographic Location. Energies, 2016. 9, DOI: https://doi.org/10.3390/en9060413.

Coventry, J., Campbell, J., Xue, Y., Hall, C., Kim, J.-S., Pye, J., Burgess, G., Lewis, D., Nathan, G., Arjomandi, M., Stein, W., Blanco, M., Barry, J., Doolan, M., Lipinski, W. and Beath, A. (2016). Heliostat Cost Down Scoping Study - Final Report.

CSI-ECRA, Development of the State of the Art-techniques in Cement Manufacturing: Trying to Look Ahead, European Cement Research Academy, 2017.

Cuéllar-Franca, R. M. and Azapagic, A. Carbon capture, storage and utilisation technologies: $A$ critical analysis and comparison of their life cycle environmental impacts. Journal of $\mathrm{CO}_{2}$ Utilization, 2015. 9, 82-102 DOI: https://doi.org/10.1016/j.jcou.2014.12.001.

Damtoft, J. S., Lukasik, J., Herfort, D., Sorrentino, D. and Gartner, E. M. Sustainable development and climate change initiatives. Cement and Concrete Research, 2008. 38, 115-127 DOI: https://doi.org/10.1016/j.cemconres.2007.09.008.

Dryden, I. G. C., Furnaces: principles of design and use, in The Efficient Use of Energy, 1982. p. 116-165.

EMEP/EEA, Manufacturing industries and construction (combustion). Emission inventory guidebook, 2013.

EPA, Greenhouse Gas Emissions from a Typical Passenger Vehicle. EPA, 2020; Available from: https://www.epa.gov/greenvehicles/greenhouse-gas-emissions-typical-passenger-vehicle. 
EU, Directive 2000/76/EC of the European Parliament and of the Council of 4 December 2000 on the incineration of waste.

EU, Directive 2008/98/EC of the European Parliament and of the Council. Official Journal of the European Union, 2008, 3-30.

EU, Waste Electrical and Electronic Equipment. Union, E. Official Journal of the European Union, 34 (2019) 194-227.

Gagliano, A., Aneli, S. and Nocera, F. Analysis of the performance of a building solar thermal façade (BSTF) for domestic hot water production. Renewable Energy, 2019. 142, 511-526 DOI: https://doi.org/10.1016/j.renene.2019.04.102.

García-Gusano, D., Garraín, D., Herrera, I., Cabal, H. and Lechón, Y. Life Cycle Assessment of applying $\mathrm{CO}_{2}$ post-combustion capture to the Spanish cement production. Journal of Cleaner Production, 2015. 104, 328-338 DOI: https://doi.org/10.1016/j.jclepro.2013.11.056.

García-Gusano, D., Herrera, I., Garraín, D., Lechón, Y. and Cabal, H. Life cycle assessment of the Spanish cement industry: implementation of environmental-friendly solutions. Clean Technologies and Environmental Policy, 2014. 17, 59-73 DOI: https://doi.org/10.1007/s10098-014-0757-0.

Garcia Garcia, J. P., Personal communication 2019.

Georgiopoulou, M. and Lyberatos, G. Life cycle assessment of the use of alternative fuels in cement kilns: A case study. J Environ Manage, 2018. 216, 224-234 DOI: https://doi.org/10.1016/j.jenvman.2017.07.017.

Gruenewald, M. and Radnjanski, A., Gas-liquid contactors in liquid absorbent-based PCC, in Absorption-Based Post-combustion Capture of Carbon Dioxide. 2016. p. 341-363.

Güereca, L. P., Torres, N. and Juárez-López, C. R. The co-processing of municipal waste in a cement kiln in Mexico. A life-cycle assessment approach. Journal of Cleaner Production, 2015. 107, 741-748 DOI: https://doi.org/10.1016/i.jclepro.2015.05.085.

Habert, G., Billard, C., Rossi, P., Chen, C. and Roussel, N. Cement production technology improvement compared to factor 4 objectives. Cement and Concrete Research, 2010. 40, 820-826 DOI: https://doi.org/10.1016/j.cemconres.2009.09.031.

Hasanbeigi, A., Lu, H., Williams, C. and Price, L. (2012). International Best Practices for PreProcessing and Co-Processing Municipal Solid Waste and Sewage Sludge in the Cement Industry, Lawrence Berkeley National Laboratory.

Hills, T., Florin, N. and Fennell, P. S. Decarbonising the cement sector: A bottom-up model for optimising carbon capture application in the UK. Journal of Cleaner Production, 2016. 139, 1351-1361 DOI: https://doi.org/10.1016/j.jclepro.2016.08.129.

Holt, S. P. and Berge, N. D. Life-cycle assessment of using liquid hazardous waste as an alternative energy source during Portland cement manufacturing: A United States case study. Journal of Cleaner Production, 2018. 195, 1057-1068 DOI: https://doi.org/10.1016/j.jclepro.2018.05.214.

Hossain, M. U., Poon, C. S., Kwong Wong, M. Y. and Khine, A. Techno-environmental feasibility of wood waste derived fuel for cement production. Journal of Cleaner Production, 2019. 230, 663-671 DOI: https://doi.org/10.1016/j.jclepro.2019.05.132.

Hossain, M. U., Poon, C. S., Lo, I. M. C. and Cheng, J. C. P. Comparative LCA on using waste materials in the cement industry: A Hong Kong case study. Resources, Conservation and Recycling, 2017. 120, 199-208 DOI: https://doi.org/10.1016/j.resconrec.2016.12.012.

Huijbregts, M. A. J., Steinmann, Z. J. N., Elshout, P. M. F., Stam, G., Vieira, M. D. M., Hollander, A., Zijp, M. and van Zelm, R. (2016). ReCiPe 2016 - A harmonized life cycle impact assessment method at midpoint and endpoint level - Report I: Characterization. Bilthoven, The Netherlands, Ministry of Health, Wlefare and Sport.

IEA, $\mathrm{CO}_{2}$ Capture in the Cement Industry, International Energy Agency Greenhouse Gas R\&D Programme, 2008.

IEA, Direct $\mathrm{CO}_{2}$ intensity of cement in the Sustainable Development Scenario, 2014-2030. IEA, Paris, 2019.

ISO, ISO 14040, Environmental Management - Life Cycle Assessment - Principles and Framework. Geneva, 2006a.

ISO, ISO 14044, Environmental Management - Life Cycle Assessment - Requirements and Guidelines. Geneva, 2006b. 
Janjai, S., Laksanaboonsong, J. and Seesaard, T. Potential application of concentrating solar power systems for the generation of electricity in Thailand. Applied Energy, 2011. 88, 4960-4967 DOI: https://doi.org/10.1016/j.apenergy.2011.06.044.

Johnston. Sweeper Range - Worldwide. 2018; Available from: https://www.johnstonsweepers.co.uk/wp-content/uploads/2017/12/johnston-sweepers-br18226.pdf.

Kääntee, U., Zevenhoven, R., Backman, R. and Hupa, M. Cement manufacturing using alternative fuels and the advantages of process modelling. Fuel Processing Technology, 2004. 85, 293301 DOI: https://doi.org/10.1016/S0378-3820(03)00203-0.

Kelly, B. D. Advanced Thermal Storage for Central Receivers with Supercritical Coolants. 2010. DOI: http://dx.doi.org/10.2172/981926.

Khaniabadi, Y. O., Sicard, P., Taiwo, A. M., De Marco, A., Esmaeili, S. and Rashidi, R. Modeling of particulate matter dispersion from a cement plant: Upwind-downwind case study. Journal of Environmental Chemical Engineering, 2018. 6, 3104-3110 DOI: https://doi.org/10.1016/j.jece.2018.04.022.

Lamnatou, C. and Chemisana, D. Concentrating solar systems: Life Cycle Assessment (LCA) and environmental issues. Renewable and Sustainable Energy Reviews, 2017. 78, 916-932 DOI: https://doi.org/10.1016/j.rser.2017.04.065.

Leonardi, E., Pisani, L., Les, I., Larrayoz, A. M., Rohani, S. and Schöttl, P. Techno-economic heliostat field optimization: Comparative analysis of different layouts. Solar Energy, 2019. 180, 601-607 DOI: https://doi.org/10.1016/..solener.2019.01.053.

Li, J., Tharakan, P., Macdonald, D. and Liang, X. Technological, economic and financial prospects of carbon dioxide capture in the cement industry. Energy Policy, 2013. 61, 1377-1387 DOI: https://doi.org/10.1016/j.enpol.2013.05.082.

Lopez, A., Personal communication, 2019.

Machner, A., Zajac, M., Ben Haha, M., Kjellsen, K. O., Geiker, M. R. and De Weerdt, K. Stability of the hydrate phase assemblage in Portland composite cements containing dolomite and metakaolin after leaching, carbonation, and chloride exposure. Cement and Concrete Composites, 2018. 89, 89-106 DOI: https://doi.org/10.1016/i.cemconcomp.2018.02.013.

Meier, A., Bonaldi, E., Cella, G. M., Lipinski, W. and Wuillemin, D. Solar chemical reactor technology for industrial production of lime. Solar Energy, 2006. 80, 1355-1362 DOI: https://doi.org/10.1016/j.solener.2005.05.017.

Meier, A., Gremaud, N. and Steinfeld, A. Economic evaluation of the industrial solar production of lime. Energy Conversion and Management, 2005. 46, 905-926 DOI: https://doi.org/10.1016/j.enconman.2004.06.005.

Mikhailova, O., Yakovlev, G., Maeva, I. and Senkov, S. Effect of Dolomite Limestone Powder on the Compressive Strength of Concrete. Procedia Engineering, 2013. 57, 775-780 DOI: https://doi.org/10.1016/j.proeng.2013.04.098.

Moora, H., Roos, I., Kask, U., Kask, L. and Ounapuu, K. Determination of biomass content in combusted municipal waste and associated $\mathrm{CO}_{2}$ emissions in Estonia. Energy Procedia, 2017. 128, 222-229 DOI: 10.1016/j.egypro.2017.09.059.

Moumin, G., Ryssel, M., Zhao, L., Markewitz, P., Sattler, C., Robinius, M. and Stolten, D. $\mathrm{CO}_{2}$ emission reduction in the cement industry by using a solar calciner. Renewable Energy, 2020. 145, 1578-1596 DOI: https://doi.org/10.1016/i.renene.2019.07.045.

Moumin, G., Tescari, S., Sundarraj, P., de Oliveira, L., Roeb, M. and Sattler, C. Solar treatment of cohesive particles in a directly irradiated rotary kiln. Solar Energy, 2019. 182, 480-490 DOI: https://doi.org/10.1016/j.solener.2019.01.093.

Oliveira, F. A. C., Fernandes, J. C., Galindo, J., Rodríguez, J., Cañadas, I., Vermelhudo, V., Nunes, A. and Rosa, L. G. Portland cement clinker production using concentrated solar energy-A proof-of-concept approach. Solar Energy, 2019. 183, 677-688 DOI: https://doi.org/10.1016/j.solener.2019.03.064.

Panahandeh, A., Asadollahfardi, G. and Mirmohammadi, M. Life cycle assessment of clinker production using refuse-derived fuel: $A$ case study using refuse-derived fuel from Tehran municipal solid waste. Environmental Quality Management, 2017. 27, 57-66 DOI: https://doi.org/10.1002/tqem.21513. 
Penistone, A. 2018 UK Greenhouse Gases Emissions, Provisional Figures. 2019. Available from: https://www.gov.uk/government/collections/final-uk-greenhouse-gas-emissions- nationalstatistics.

Quaschning, V. Technical and economical system comparison of photovoltaic and concentrating solar thermal power systems depending on annual global irradiation. Solar Energy, 2004. 77, 171-178 DOI: https://doi.org/10.1016/i.solener.2004.04.011.

Rahman, A., Rasul, M. G., Khan, M. M. K. and Sharma, S. Impact of Alternative Fuels on the Cement Manufacturing Plant Performance: An Overview. Procedia Engineering, 2013. 56, 393-400 DOI: https://doi.org/10.1016/j.proeng.2013.03.138.

Rahman, A., Rasul, M. G., Khan, M. M. K. and Sharma, S. Recent development on the uses of alternative fuels in cement manufacturing process. Fuel, 2015. 145, 84-99 DOI: https://doi.org/10.1016/j.fuel.2014.12.029.

REE, The Spanish Electricity System: Preliminary Report, Red Electrica de Espana, 2019, Available from:

https://www.ree.es/sites/default/files/11_PUBLICACIONES/Documentos/InformesSistemaEle ctrico/2019/Avance_ISE_2018_en.pdf .

Richards, G. and Agranovski, I. E. Air emission from the co-combustion of alternative derived fuels within cement plants: Gaseous pollutants. J Air Waste Manag Assoc, 2015. 65, 186-196 DOI: https://doi.org/10.1080/10962247.2014.984084.

Richardson, J. F., Harker, J. H. and Backhurst, J. R., Fluidisation, in Chemical Engineering. 2002. p. 291-371.

Rolfe, A., Huang, Y., Haaf, M., Pita, A., Rezvani, S., Dave, A. and Hewitt, N. J. Technical and environmental study of calcium carbonate looping versus oxy-fuel options for low $\mathrm{CO}_{2}$ emission cement plants. International Journal of Greenhouse Gas Control, 2018. 75, 85-97 DOI: https://doi.org/10.1016/j.ijggc.2018.05.020.

Ruan, S. and Unluer, C. Comparative life cycle assessment of reactive $\mathrm{MgO}$ and Portland cement production. Journal of Cleaner Production, 2016. 137, 258-273 DOI: https://doi.org/10.1016/j.jclepro.2016.07.071.

Saghafifar, M., Gadalla, M. and Mohammadi, K. Thermo-economic analysis and optimization of heliostat fields using AINEH code: Analysis of implementation of non-equal heliostats (AINEH). Renewable Energy, 2019. 135, 920-935 DOI: https://doi.org/10.1016/j.renene.2018.12.060.

Sansom, M. M., J (2013). Life-cycle assessment (LCA) for steel construction, Directorate-General for Research and Innovation (European Commission).

SCARAB-FAYAT. Road Sweeper. 2019; Available from: https://www.scarabsweepers.com/Products/merlin.php.

Schakel, W., Hung, C. R., Tokheim, L.-A., Strømman, A. H., Worrell, E. and Ramírez, A. Impact of fuel selection on the environmental performance of post-combustion calcium looping applied to a cement plant. Applied Energy, 2018. 210, 75-87 DOI: https://doi.org/10.1016/j.apenergy.2017.10.123.

Seyler, C., Hellweg, S., Monteil, M. and Hungerbühler, K. Life Cycle Inventory for Use of Waste Solvent as Fuel Substitute in the Cement Industry - A Multi-Input Allocation Model (11 pp). The International Journal of Life Cycle Assessment, 2004. 10, 120-130 DOI: http://dx.doi.org/10.1065/lca2004.08.173.

Siqueira-Silva, A. I., Pereira, E. G., Modolo, L. V., Lemos-Filho, J. P. and Paiva, E. A. Impact of cement dust pollution on Cedrela fissilis Vell. (Meliaceae): A potential bioindicator species. Chemosphere, 2016. 158, 56-65 DOI: https://doi.org/10.1016/i.chemosphere.2016.05.047.

Solargis. Global Solar Atlas, 2016, Available from: https://globalsolaratlas.info/downloads/world.

SOLPART, SOLPART project, 2019, Available from: https://www.solpart-project.eu/.

Souliotis, M., Arnaoutakis, N., Panaras, G., Kavga, A. and Papaefthimiou, S. Experimental study and Life Cycle Assessment (LCA) of Hybrid Photovoltaic/Thermal (PV/T) solar systems for domestic applications. Renewable Energy, 2018. 126, 708-723 DOI: https://doi.org/10.1016/j.renene.2018.04.011.

SRI, Steel Takes LEED® with Recycled Content, 2009, Available from: https://www.steelsustainability.org/Recycling\%20Resources/ /media/Files/SRI/Media\%20Ce nter/LEEDNov09.ashx. 
Stafford, F. N., Raupp-Pereira, F., Labrincha, J. A. and Hotza, D. Life cycle assessment of the production of cement: A Brazilian case study. Journal of Cleaner Production, 2016. 137, 1293-1299 DOI: https://doi.org/10.1016/j.jclepro.2016.07.050.

Thinkstep, GaBi. 2019; Available from: https://www.thinkstep.com/.

Tosti, L., van Zomeren, A., Pels, J. R., Damgaard, A. and Comans, R. N. J. Life cycle assessment of the reuse of fly ash from biomass combustion as secondary cementitious material in cement products. Journal of Cleaner Production, 2020. 245, DOI: https://doi.org/10.1016/j.jclepro.2019.118937.

Tregambi, C., Solimene, R., Montagnaro, F., Salatino, P., Marroccoli, M., Ibris, N. and Telesca, A. Solar-driven production of lime for ordinary Portland cement formulation. Solar Energy, 2018. 173, 759-768 DOI: https://doi.org/10.1016/j.solener.2018.08.018.

Tsiligiannis, A. and Tsiliyannis, C. Renewable energy in cement manufacturing: A quantitative assessment of energy and environmental efficiency of food residue biofuels. Renewable and Sustainable Energy Reviews, 2019. 107, 568-586 DOI: https://doi.org/10.1016/j.rser.2019.03.009.

Tsiliyannis, C. A. Cement manufacturing using alternative fuels: Enhanced productivity and environmental compliance via oxygen enrichment. Energy, 2016. 113, 1202-1218 DOI: https://doi.org/10.1016/j.energy.2016.07.082.

UNIDO Global Technology Roadmap for CCS in Industry. Sectoral Workshops Report - Annexes, United Nations Industrial Development Organization, 2010.

USGS, Cement statistics and information, 2019, Available from: https://www.usgs.gov/centers/nmic/cement-statistics-and-information.

Volkart, K., Bauer, C. and Boulet, C. Life cycle assessment of carbon capture and storage in power generation and industry in Europe. International Journal of Greenhouse Gas Control, 2013. 16, 91-106 DOI: https://doi.org/10.1016/j.ijggc.2013.03.003.

Wang, J., Duan, L., Yang, Y. and Yang, L. Rapid design of a heliostat field by analytic geometry methods and evaluation of maximum optical efficiency map. Solar Energy, 2019. 180, 456467 DOI: https://doi.org/10.1016/j.solener.2019.01.052.

Wernet, G., Bauer, C., Steubing, B., Reinhard, J., Moreno-Ruiz, E. and Weidema, B. The ecoinvent database version 3 (part I): overview and methodology. The International Journal of Life Cycle Assessment, 2016. 21, 1218-1230 DOI: https://doi.org/10.1007/s11367-016-1087-8.

Yadav, N. K., Pala, D. and Chandra, L. On the Understanding and Analyses of Dust Deposition on Heliostat. Energy Procedia, 2014. 57, 3004-3013 DOI: https://doi.org/10.1016/j.egypro.2014.10.336.

Yang, D., Fan, L., Shi, F., Liu, Q. and Wang, Y. Comparative study of cement manufacturing with different strength grades using the coupled LCA and partial LCC methods-A case study in China. Resources, Conservation and Recycling, 2017. 119, 60-68 DOI: https://doi.org/10.1016/j.resconrec.2016.06.017.

YMG. Weather Atlas: Alicante, Spain. 2020 [cited 2020; Available from: https://www.weatheres.com/en/spain/alicante-climate.

Zemba, S., Ames, M., Green, L., Botelho, M. J., Gossman, D., Linkov, I. and Palma-Oliveira, J. Emissions of metals and polychlorinated dibenzo(p)dioxins and furans (PCDD/Fs) from Portland cement manufacturing plants: inter-kiln variability and dependence on fuel-types. Sci Total Environ, 2011. 409, 4198-4205 DOI: https://doi.org/10.1016/j.scitotenv.2011.06.047.

Zieri, W. and Ismail, I. (2018). Alternative Fuels from Waste Products in Cement Industry. Handbook of Ecomaterials, Springer, Cham. 
Assessing the environmental sustainability of an emerging energy technology: Solar thermal calcination for cement production

Marco Tomatis, Harish Kumar Jeswani, Laurence Stamford and Adisa Azapagic

\section{Supplementary information}

Table S1 Spanish electricity mix ${ }^{a}$

\begin{tabular}{ll}
\hline Source & Contribution (\%) \\
\hline Fossil fuels & 39.2 \\
Hard coal & 13.5 \\
Natural gas & 10.2 \\
Natural gas - combined heat and power & 11.2 \\
Oil & 4.3 \\
Nuclear & 20.6 \\
Pressurised water reactor & 15.9 \\
Boiling water reactor & 4.7 \\
Waste & 1.2 \\
Non-renewable & 0.9 \\
Renewable & 0.3 \\
Renewables & 39 \\
Solar thermal & 1.7 \\
Photovoltaics & 2.9 \\
Hydro pumped storage & 0.8 \\
Hydro reservoir & 4.5 \\
Hydro run-off-river & 8.7 \\
Wind & 19 \\
Biogas & 1.4 \\
\hline Source: REE (2019). The Spanish Electricity System: Preliminary Report. Red Electrica de Espana.
\end{tabular}




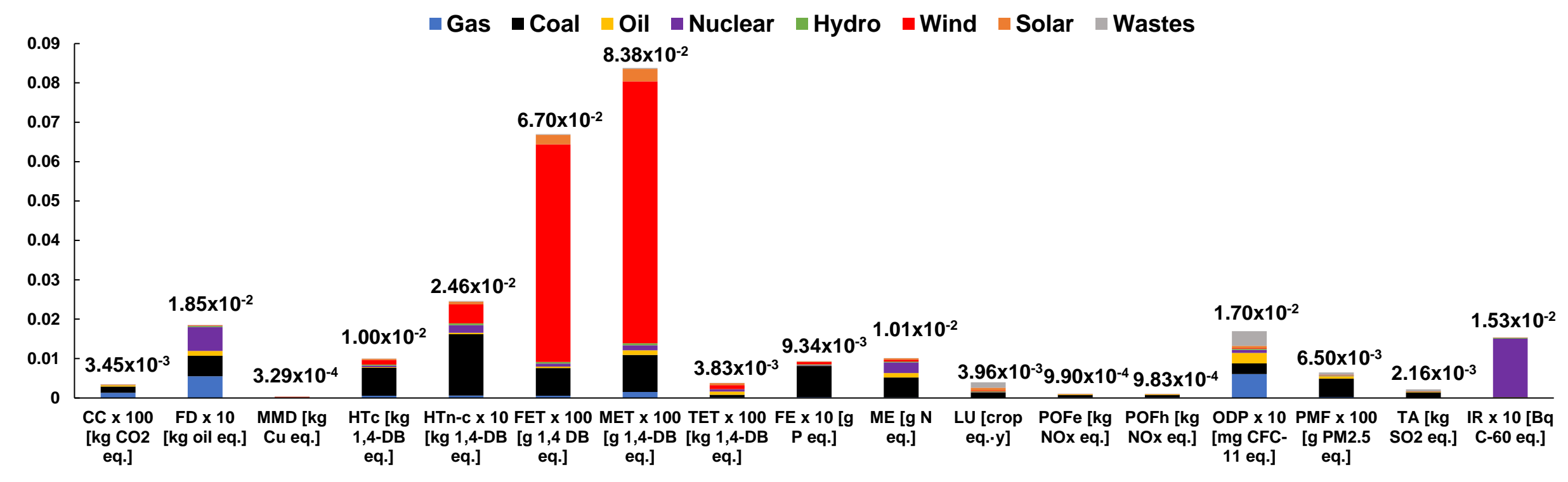

\section{Figure S1 Environmental impacts of Spanish electricity}

[The impacts relate to the electricity mix in Table S1 and are expressed per kWh of electricity generated. Some impacts have been scaled to fit. To obtain the original values, multiply with the factor on the x-axis, where relevant. CC: climate change; FD: fossil depletion; MMD: metals and minerals depletion; HTc: human toxicity cancer; HTn-c: human toxicity non-cancer; FET: freshwater ecotoxicity; MET: marine ecotoxicity; TET: terrestrial ecotoxicity; FE: freshwater eutrophication; ME: marine eutrophication; LU: land use; POFe: photochemical ozone formation - ecosystems; POFh: photochemical ozone formation - human health; ODP: ozone depletion potential; PMF: particulate matter formation;

TA: terrestrial acidification; IR: ionizing radiation. DB: dichlorobenzene.]. 


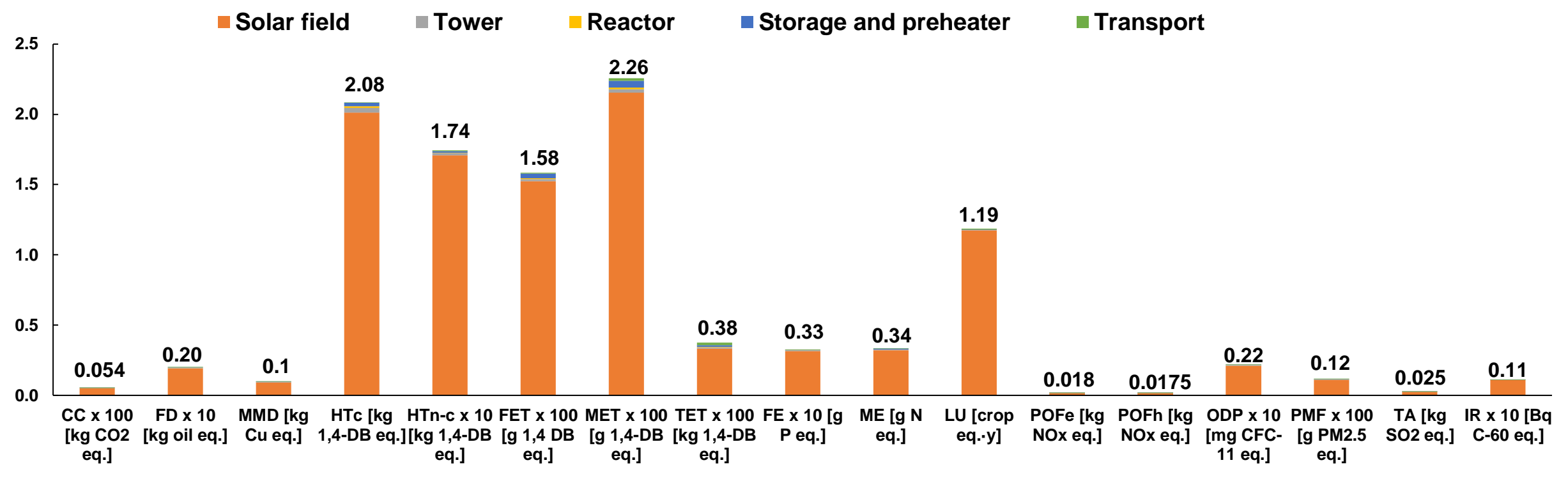

Figure S2 Environmental impacts of constructing solar facilities

[All impacts are expressed per tonne of calcined cement raw meal. Some impacts have been scaled to fit. To obtain the original values, multiply with the factor on the x-axis, where relevant. For the abbreviations, see Figure S1.]. 


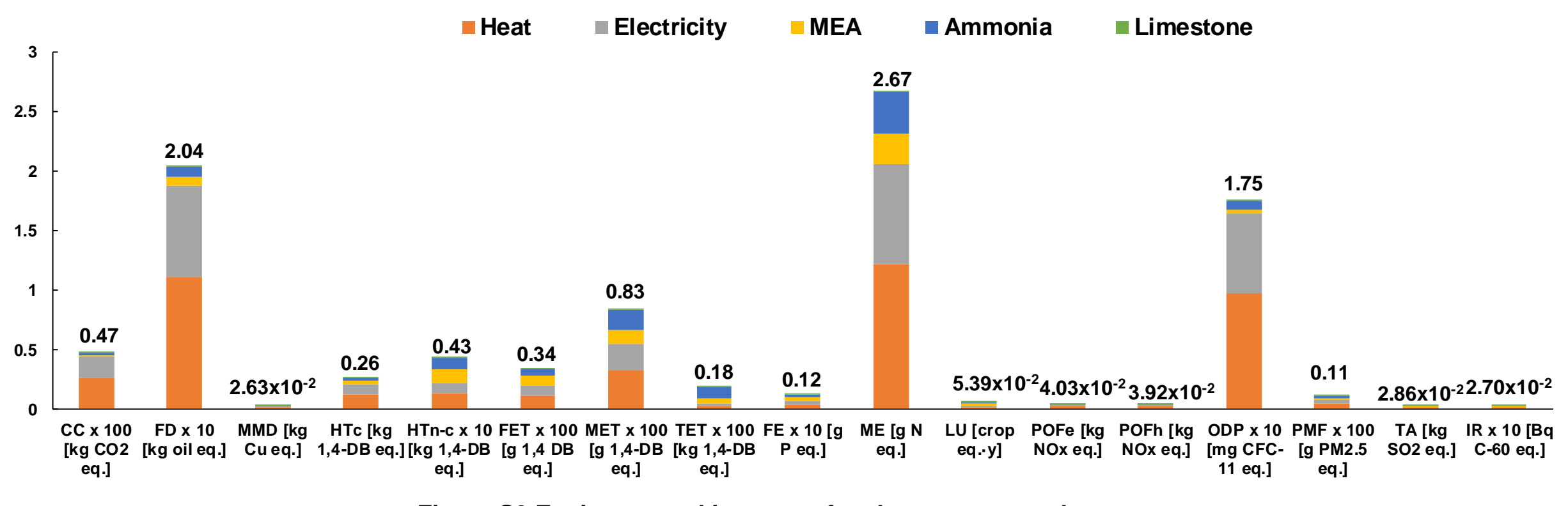

Figure S3 Environmental impacts of carbon capture and storage

[All impacts are expressed per tonne of calcined cement raw meal. Some impacts have been scaled to fit. To obtain the original values, multiply with the factor on the $x$-axis, where relevant. For the abbreviations, see Figure S1.]. 